\title{
膠質狀態に在ろ物質の静脈內注射による 急性死の發生機轉に就て
}

\section{（第 $\quad 1$ 報）}

\author{
醫學士 熊 谷 直 俊
}

（千装醫科大學藥理學敉室〔主任 林敎授〕）

(昭和十七年三月二十五日受付)

\section{目}

緒 言

I. Kolloid-銀溶液の静脈內注射後に於 ける症狀並、解剖所見

1. 本篇の主題に就て

2. Schock-症狀
a 非死亡例
b 急性死例
c 遲發夗例

3. 解剖所見
a 急性死例
b 非死亡例
c 㜊發死例

4. 所謂急性死の定義其の他

IJ. Kolloid-銀溶液の濃度が致死作用に 及ぼす影響

1. 本篇の主題に就て

2. 濃度と致死作用とに關する實驗

a 賽驗材料其の他

b Kolloid-銀對 $\mathrm{kg} 0,16 \mathrm{~g}$ を濃度を

異にして注射した實驗
次

c Kolloid-銀溶液對 $\mathrm{kg} 2 \mathrm{cc}$ を濃度 を異にして注射した實驗

d 小 括

3. 膠質溶液の紊透㗨の見地から行つ た實驗

4. 血小板の破壤が急性死の發生を誘 發する一因子となるか

5. 赤血球の破壤が急性死の發生を誘 發する一因子となるか

6. 蒸餾水對 $\operatorname{kg} 7,2 \mathrm{cc}$ の静脈內注射で 何程の溶血が惹起されるか

7. 溶血現像だけで急性死か起るか

8，Kolloid-銀自身の溶血作用は急性 死の發生に關與するか

9. 赤血球の成分中急性死の發生に關 與寸る物質は內漿に在るか，礎質 に在るか

10. 總括並に結論 引用書目

\section{緒}

言

腠質狀態にある物質例へば Salvarsan, Agar-Agar, Inulin, Kollargol 等つ水溶液を動

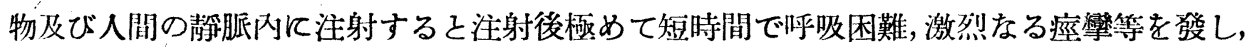
急速江死亡する事がある.此の所謂急性死なる現象はかなり以前から知られて居たが，其の 後 Kollargol 其の他種々の金屬-Kolloid-製劑の靜脈內投與が治療の 目的で廣く應用される に至つてから此の不幸な出來事がしばしば設生したので更に注意を惹くに至つた. 而して 此の急性死の直接の原因が生體內で血管內血液凝固老來す爲である事も既に Rost ${ }^{1}$ )が Kollargol 注射に於て指摘して居る處である.氏は屍體に見られる凝血が生前て發生したるのか 
又は死後に發生したものかと云ふ問題の研究に於て生前に發生したThrombus の形態學的 檢索をするためにKollargol-溶液の静脈內注射によつて動物を㤵死させたのである。我が

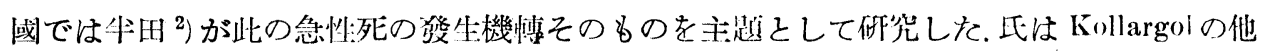

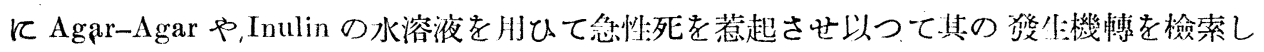

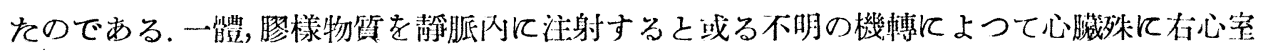

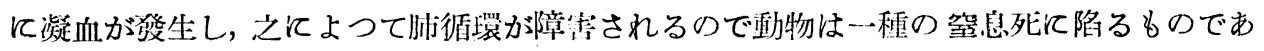

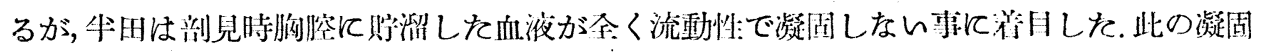
性を失つた血液に就て研党した絬果, 氏其の非㠜固性が核血液て Fibrinogen が缺除して

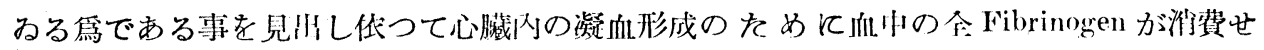
られたものであると考へたらしん。.そして此の現象をDefibrination そ稱した。然しながら

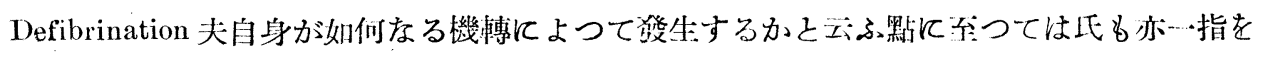

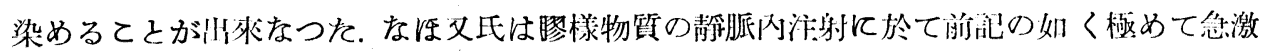

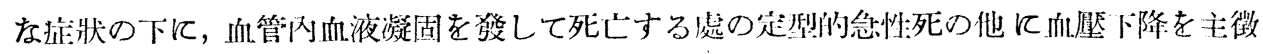

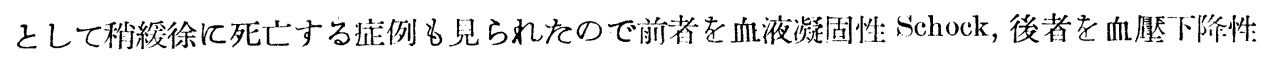

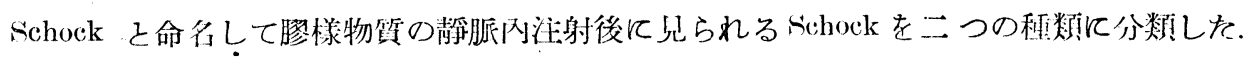

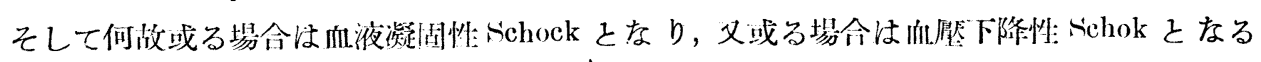

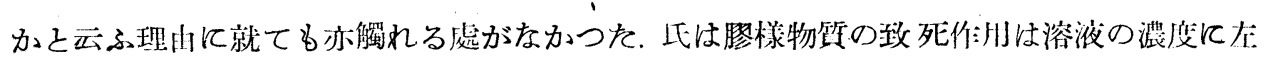
存される事が多いらしく從つて最小致死最の決分注困難であると云つてみる. 忆㺫以後多

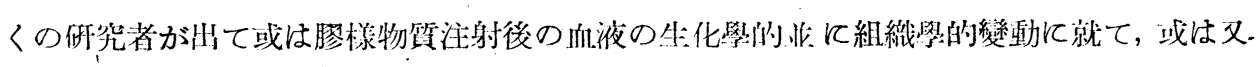

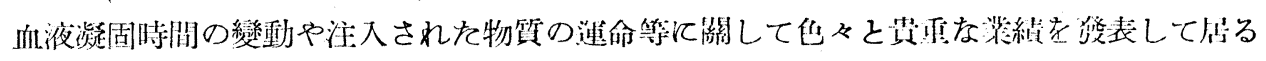

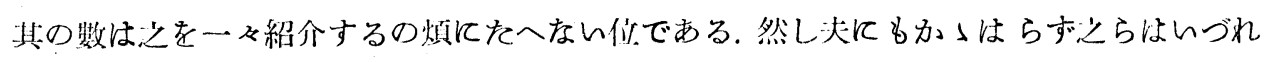

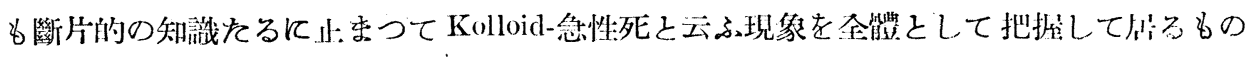

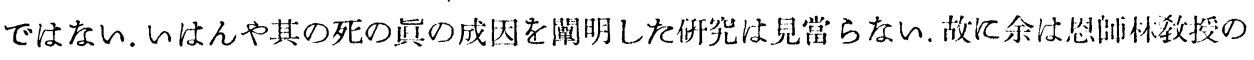

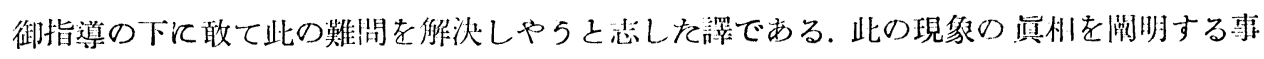

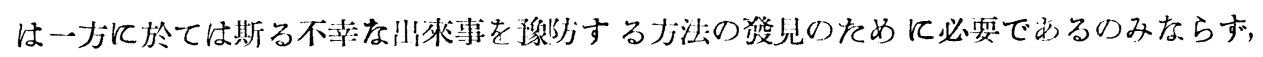

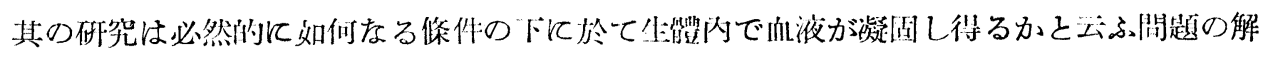

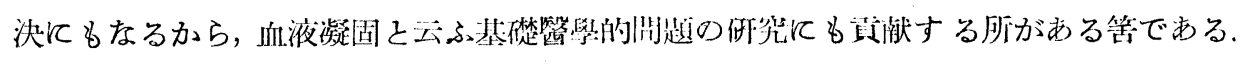

\section{Kolloid-銀溶液の靜胍內注射後に於ける症狀道に解剖所見}

\section{1. 本篇の主題に就て}

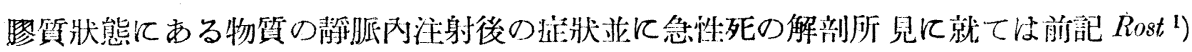

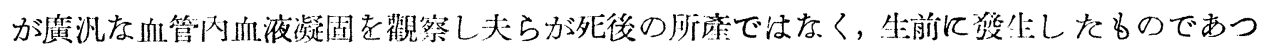

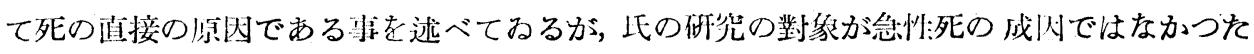


ので該凝血の形態學的祀述の兄夺であるともかなはらす急性死の症狀の記述としては聊か

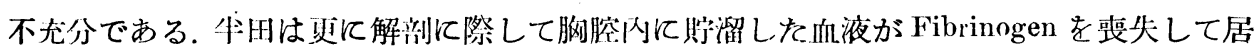
るためて凝固しない事を認めて全血液中のFibrinogen が心藏內凝血の形成の雹に消費せら れたものと将へた可は前述の通りである. 然し氏も亦急性死の症狀や解剖所見に關しては 声だ简單に記述して居るのみである. 氏らの他にも急性死の造: 狀を記述して居る人を散見 するが、んづれる論ずるに足りない.かくの如く急性死の应狀並に解剖所見を全體として詳 細に記載してみるものが少いと云ふ理由の他に，所謂急性死と云はれる現象を自 ら實驗し て屈ない人の理解を容易にする爲と又一方には是等の觀察に於て知り得た諸事實が以下の 實驗の動機となり，急性死の弡生機轉に關して贵重な暗示を與へて哭れたから, 余は余の賽 驗條件の下で發生した急性死の掟狀を一括して述べようと思ふ。本篇に記す所は凡べて第 II 篇の實驗例で觀察した所である.

\section{Schock-症狀}

\section{a. 非 死 亡 例}

注射終了後家无を固定箱から出して林の上に放ち，少しく離れて之を觀察すれば多く

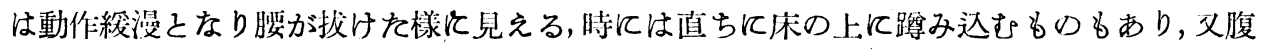
をべタリと床につけ，次いで足を伸ばしてしまふものもある．注射後 1 - $2^{\mathrm{m}}$ てなると步い て店を鬼も亦步行を止めて嗱む，耳款は蒼白，貧血性，呼吸も頻數となり，毛が立つて來て

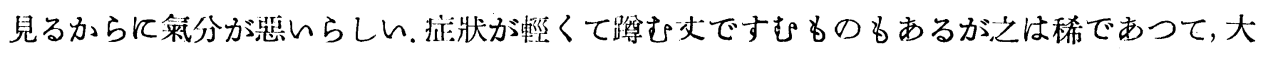
多数は腹をべタリと床につけ足を仙ばし切るるのである. 症狀が苫だ重ければ完全に側卧 位となり，耳も百もグッタリと倒して呼吸をして居る以外は全く死物の样になるものもあ る. 呼吸は注射後 2-3 $3^{\mathrm{m}}$ に至つて最も頻數となり, 全身が共に運動するに至る. 斯の如き狀 態が更に 2-3 $3^{m}$ 續した後, 即ち注射後 $5-6^{\mathrm{m}}$ 前後より呼吸は順次に緩く且つ深くなり, 10 ー15"後位になると口をモグモグさせたり猿图を見呬したりする.而して直ちに起を上つ て身づくろひをする.毛韭る美しくなる.やがて慨を求め又は恰好な隐れ場所を物色して步 き州す。時に一旦步き州して文訬び蹨む事もあるが, 其の場合でも元氣を恢復して居る事は 一見してかかる. Schock-怔狀から恢復した日安を何の點に置いてよいか不明であるが便宜 上外部からの刺㦸を俟たないで自發的に立ち上り又は步き出す時を Schockより恢復した 時期と定めて見ると其の時期は注射後 $10-15^{\mathrm{m}}$ 位である。

\section{b. 急 性 死 例}

急性死に終る例でも注射值媵の症狀恃其の性質に於ても强度に於ても非死じ例の場合 と大差なく, 急性死例の方が非死亡例より特に激烈だと云ふ印象は受けない.時には䀄ろ非 
死亡例の方が Schock が高度のものも認められる. 從つて突如として丞攣發作が襲來する迄 は急性死を起すかどらかを豫斷する事は出來ないるのである. 唯注意して觀察すれば急性 死飞終る例では注射後 $2-3$ で荒々しくなつてみた呼吸が緩徐とならね點が異ふ㥞に思は れるが, 夫とても必然りとは云へない. 斯くするらちて動物は诮を右右义は前後に振るか と見ると，全く突然に橫に倒ふれ首を背に引きつけて全身を反らせ手足を交代にバタつか

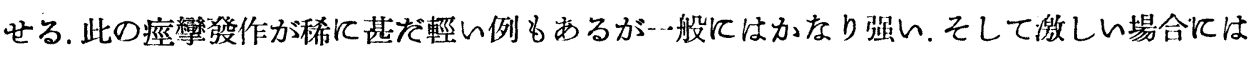
或は床より跳ね上る事もあれば, 床の上を 7-8 尺も跳ねまはる事もある. 數回又は十數问。 の痤攣發作が止む比には腿球は笑出し，瞳孔は散大し，你膜反射を消失する. 口唇は zyanotisch で側腹に小波の樣な運動が見られる, 死んたのかと思つて居ると 1-2 回少至數回の 深呼吸が思ひ出した樣に行はれる. 即ち口を大きく開を, 空氣に咬みつく樣な動作をする。 そして後完全に靜止する, 心臟は此の後もなほ相當長く運動して居る. 痤孚の終了後呼吸停

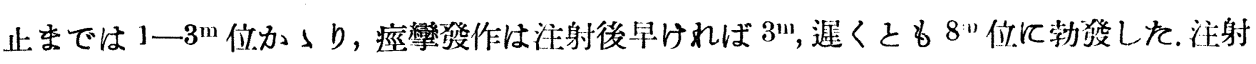
後 $10 "$ に及んでもな痤卛を見ない場合は假令腹をべタリを床につけ，足を仆ばし一見し て如何にも死にそ5に見える場合でも決して急性死を來さない. 急性死が斯くの如く注射 後凡そ8-9" までて發生し 10-15

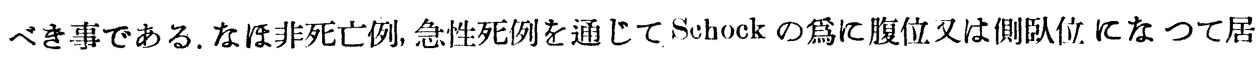
る時及び Schockより大體恢復した直後て腹壁を透して立進した腸の蠕動運動を認められ る事がある.

\section{c. 痤 墢 死 例}

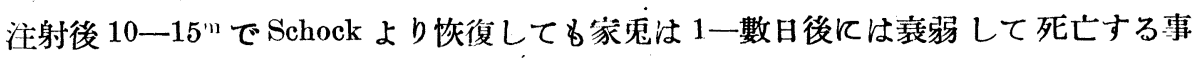

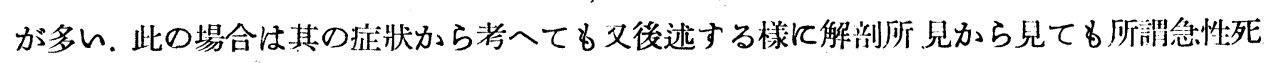
とは性質が異るもので别箇の取扱をすべきものと思はれる，仍つて余は之を急性死に對し て尷發死と名づけた。

\section{3. 解 剖 所 見 \\ a. 急 性 死 例}

呼吸の完全停止を確認した後, 直ちに胸腔を開けば心藏は莘しく大をくなり唒しばら く運動を續けて居る.下空靜脈も著しく太くなつて居て之を切斷すれば腹側亚に心噦側よ り黑い流動性血液と共に軟かん凝血が切口から流れ出る. 大動脈を切斷すれは䱢紅色の流

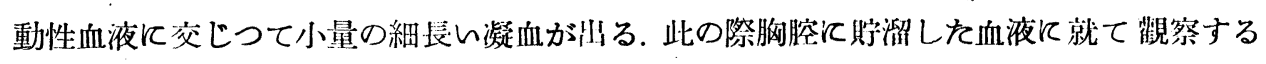
て每常流動性で疑固性なしとは云へないのである. 即ち余の例の多數に於ては不完 全では あるが胸腔內で凝固を起すのである. 勿論普通の血液と比較すれば㠜固性が少る事は争は 


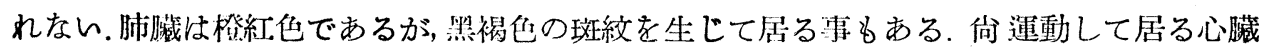

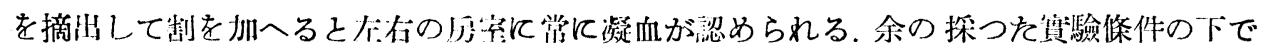
發生させた急性死例に於て萑だ興味ある所见は心瀻入で见られる凝血に2つの部分がある

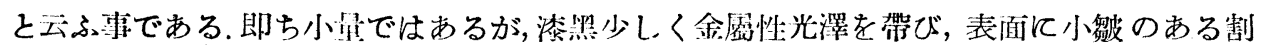

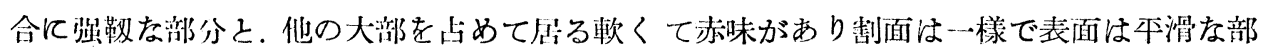

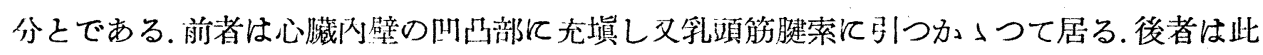

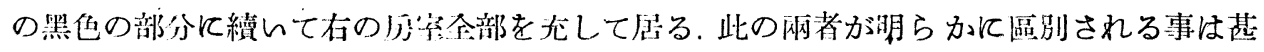

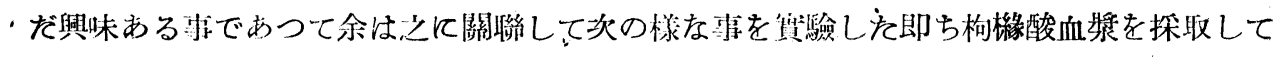
之を稀釋したものに適當品の搵化-Calcium を㞦へて凝固させるに賞つて, 前以つて血漿に

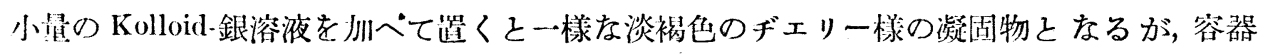

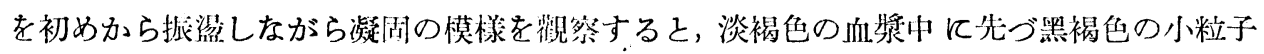
が川現し，次いで夫らがたに速䍃して細絲状となり網狀となり遂には表面に小策のある黑

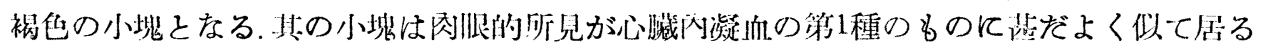
第二には家鸟の耳靜脈办ら $20 \%$ Kolloid-銀溶液對 $\mathrm{kg} 0,8 \mathrm{cc}$ を注入して数分後に頸動脈上 り採血し此の暗㫮他の血液を2つの試驗管に分注し一方を静道すれば間もなく一樣に暗黑

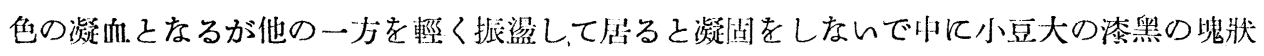

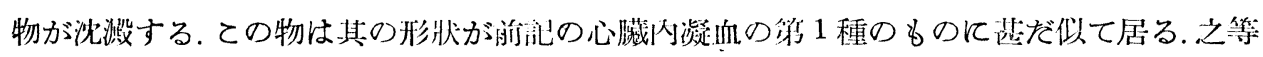

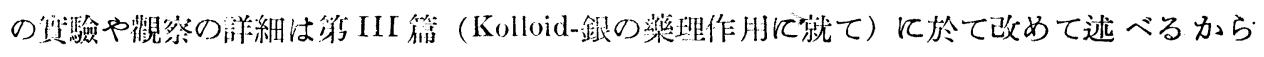

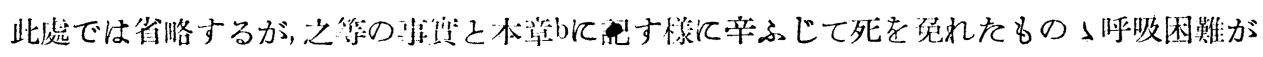

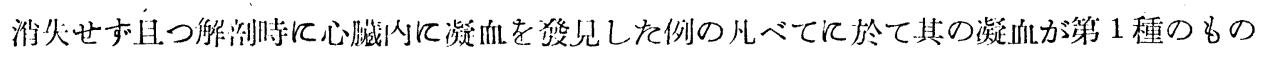

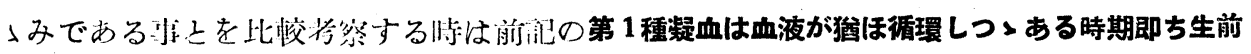
に發生したもので之に對して第 2 程の㠜血は血流停止後に, 即ちニ次的に發生したものと考へられる.

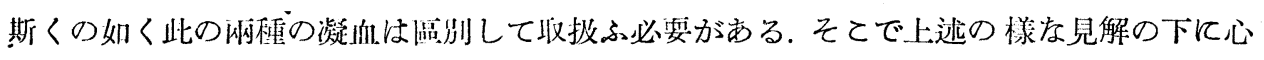

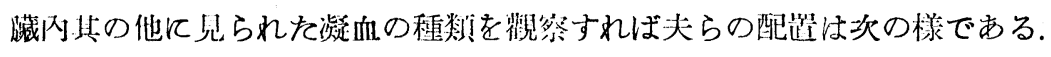

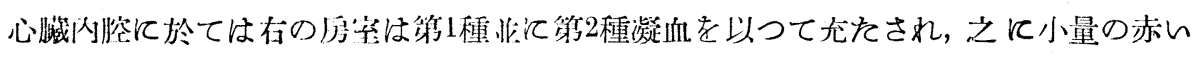

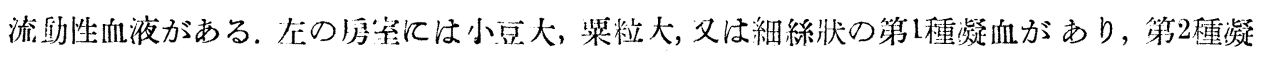

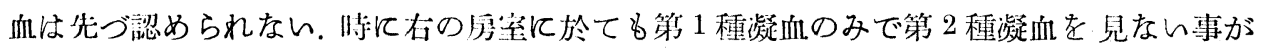

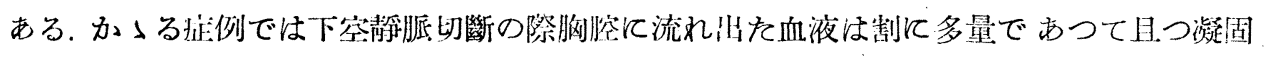

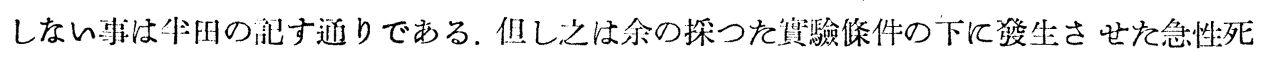

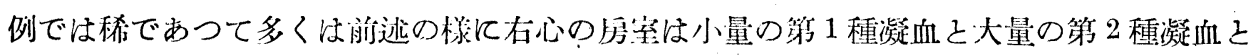

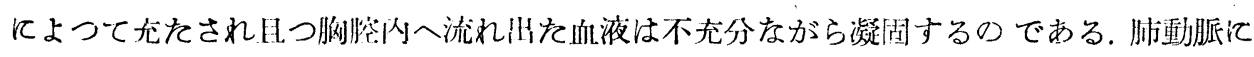

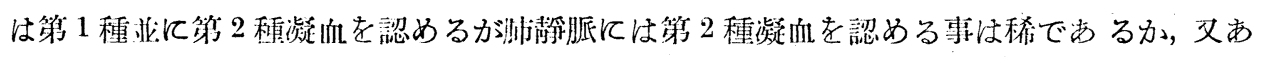

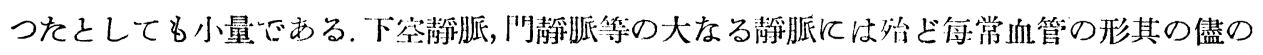


凝血が塞つて居る. 此の凝血の表面は第 1 種凝血に似て黑色で金屬性光澤を帶びては居る が表面が滑澤で全體として軟かである點江第 2 種凝血に似て居る. 總钼動脈には認められ る程の凝血はなんが, 頸靜脈は下空静脈と同樣な凝血を以つて无たされて居る. 之に反して 臘血管系飞於ては A. basilaris, A. cerebri media, A. cerebri anterior 等飞第 1 種凝血があ るが掙脈系に法凝血を認めない，開腹すれば腸管は一般にかなり强く黑染して居るが肝藏 や脾臟は制に黑染して居なん.腸の蠕動運動は克淮して扂る樣に思はれる.腸間膜を.展張し て見ると動脈には異狀はないが清脈內には微細な黑粒子（第 1 種㠜血？）が介在してみて 壓迫すれば血管內を自由に移動する、時には靜脈內を之等が行列をつくつて心臟側入流れ て行くのを見る事が出來る.

\section{b. 非 死亡 例}

Schock 加ら恢復して急性死を來さない事を碓認した後, 凡そ一時間目に頸動脈を切斷 して放血致死させ, 胸腔を開くと心臟は縮小してるるが搏動をつぐけて居る. 心劧內腔及

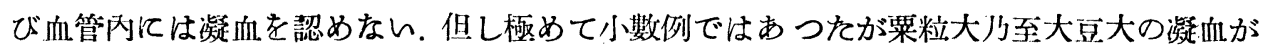
右心察に存在して居たものもあつた. そして此の際見られた凝血は第 1 種凝血であつて非 死亡例では第 2 種凝血忙決して認められなかつた. 此の樣に心藏內に凝血がありながら而 b死亡しない例では呼吸困難が注射後 $1^{\mathrm{h}}$ 以上になつても消失しなかつたから恐らくは死 筈のものが辛ふじて死を免れたものであらう. 非死亡例を注射後一時間目に解别したも のでは腸管の黑染は殆ど去り汒に反して朋, 脾壮高度に黑染して虔る.其の他の所見は急性 死の解剖所見と大差注ない。

\section{c. 遲 弡 死 例}

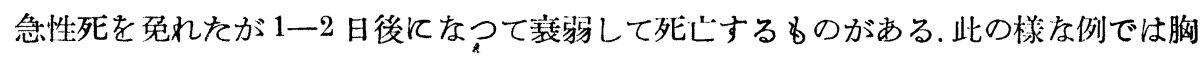
腔を開くと心藏は縮小し全身の血液は稀薄で放㯰しても凝固しなん. 胃腸管のKolloid-銀

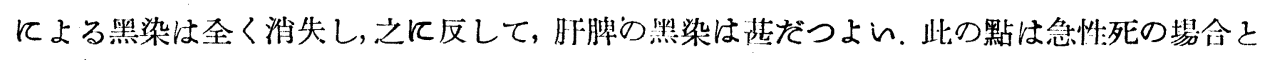
は反對である.胸腔に小量のそして腹腔には稍大量の淡袺色の深州物のある事が多い. 大網

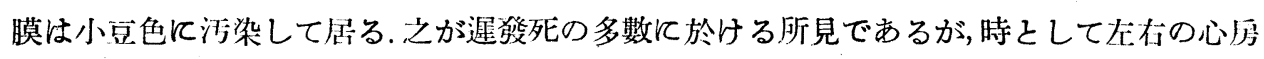

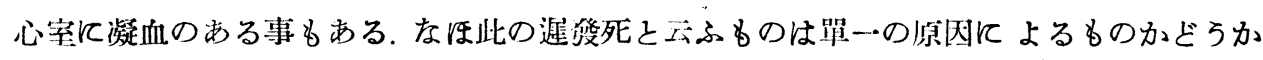
不明であつて, 恐らくは色々の成因によるものが混在してみると思はれるが余の侀究には 直接に關係する處が少んから：之れ以上觸れないでおく。

\section{4. 所謂急性死の定義其の他}

以上は余が欟察した Kolloid-銀溶液の靜脈內注射による急性死例亚沉非死亡例の鿊狀 
と解剖所見とである.之に依つて知り得る亦は二,三に止まらなん. 夫らて就ては以後の各 章に於てり用する篔であるが此處では一・二の點に就て述べる。

\section{a. 急性死の定萑}

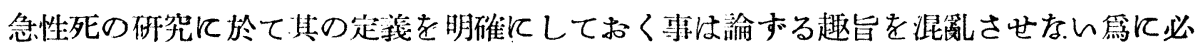
要であるから余は上述の觀察に基んて次の榚に定義を下した。

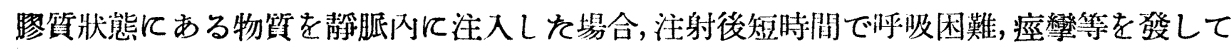
急激に死亡する怙がある。而して此の際解测すれば心藏は大きくなり唒しばらく運動す るが, 其の队腔に江凝血尤滿し此の心傤及び肺循環系の凝血によつて死ししたものと見 做し得るのである. 斯かる死を賿質溶液の猙胍內注射による急性死亡云ふ。

之が本湖究に於て余が侀究の對象とした急性死なるものである. 低つて余の所謂急性

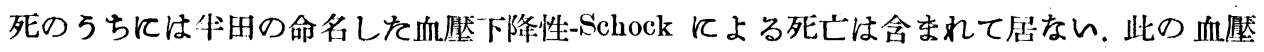
下降性-Schock と云はれる現象そのものに就ては第 III 篇以下飞於て少しく觸れるつもり である. 又後に余は Kolloid-死と云ふ語を使用する严があるが, 此のものは急性死とは别筐 の概念を指して居るのであつて余は之を急性死なる語とは區別して䏳ひて居るから兩者を 混同しない椂にせられたん。

\section{b. Kolloid-Schock の分類}

牛由が膠蜇溶液の注射による-Schockを分けて血液㠜固性-Schock そ血壓下降性Schock とになしたすは解に述べた，Eの所謂血液凝固性-Schock は余の定義した急性死飞當る。而 して半田の此の分類は急性死の淡生機轉が不明であつた當時の事とて格別の理論的根據に 基いたものではない。然しかっる分類を見ると恰も血液㠜固性-Schock と血壓下降性-Schock とは單に Schock の程度の差によつて分れる如き印象を受ける.氏亦亦かる考へを抱いて

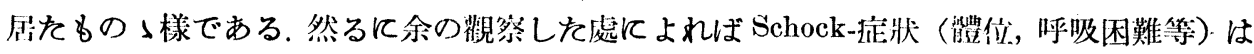

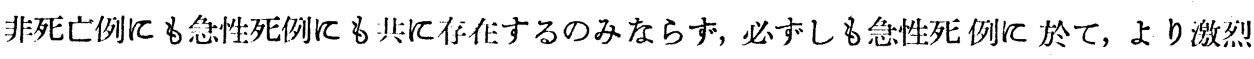
とは限らないのである. 時には Schock-势妝の激しいにもか」はらず急性死を來さないも

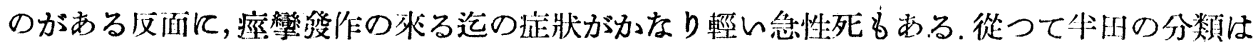
誤りではないとしても不適澢とは云はれよ5.余は管る次の如く分類するを可と信ずるも のである.

Kolloid-Schock mit intravaskulärer Koagulation (急性死)

Kolloid-Schock ohne intravaskulärer Koagulation 


\section{Kolloid-銀溶液の浱度が致死作用に及ぼす影響}

\section{1. 本篇の主題に就て}

翏質溶液の靜脈內注射によつて所請急性死を本す度合は溶液の濃度に影響される事甚 だしく, 從つて其の致死量の決定がや〉困難であるとは既几先人に低つて經驗せられた事 賽である. 但し濃度に依つて恎死作用が如何栐に影響されるものかを檢菜した研究者は我 が國では見當らなん，外國の文献を尋ねても此の點冠組織的て研究し且つ其の結果に 解釋 を與へて居るのは Messini ${ }^{3}$ )があるのみである.氏は硫兴-Sol の致死作用に就て研究した，其 の結果と解釋とを此處て簡單に引用すれば次の如くである. 即ち硫黄-Sol の溶液は濃度が 大となれば致死作用は減弱するてして其の理由として代の說く所を闑けば, 先づ硫黄-Sol

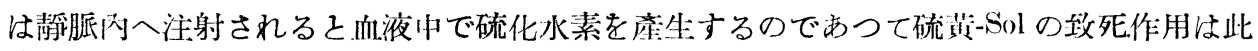

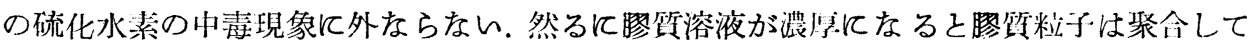
大粒子を形成する傾向が强くなつて粗大粒子となるから膠犋の分散度は減少し化學反應の

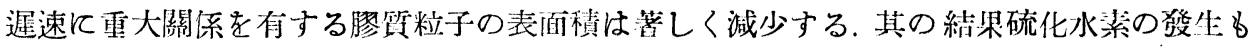

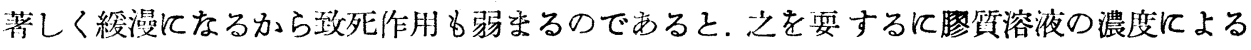
毒作用の增減は其の分散度の看減汇基くと云ふのが氏の解釋である.

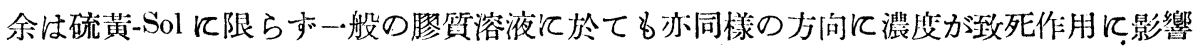

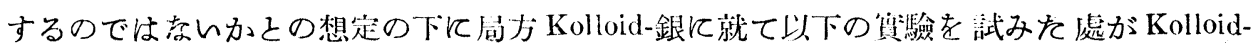

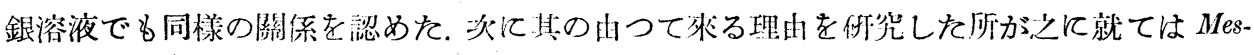

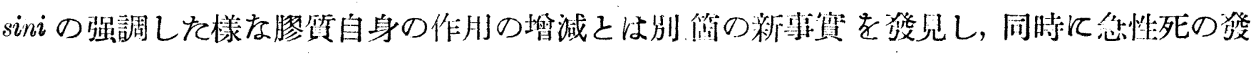
生機轉の一部を简明する事が出來をので之を本篇に於て述べる。

\section{2. 濃度と致死作用とに關する蛪驗}

\section{a.`賈驗材料其の他}

實 驗 動 物：成熟白色家鬼, 注射前約仆書夜食慨を與へない.

膠 質 溶 液：局方Kolloid-銀・櫻术”.從來此の種つ所究には Kollargol が用ひられるのか嫦 であつたから余も办同品を使用したいと思つたが現下の國祭狀攀は輸入藥品の入手を不可能ならしめ たので余は前远の如く局方 Kolloid-銀を用ひたのである.又從來急性死の研究に於ては溶媒として例外

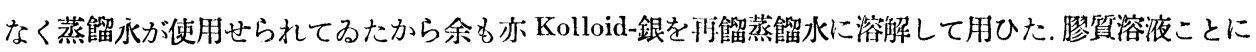
金屬の樣な hydrophob のものでは調製後時間を經過するにつれて粒子が㠜集して膠質溶液としての作 用が減弱する事も亦前記 Messini に恢つて筫騟登明されて居る. 實際余の實驗でも其の事實が認められ た.な房余の經驗によれば此の減毒的變性は溫度の高い洔期には可成急速に行はれるもの〉㨾である. 是等の理由により Kolloid-銀溶液は調製後 1兩日中に使用し了る如くし又室溫の高い夏永には之を氷 室內に保存し又各賽驗每に動物を朋ひて毒力の檢定を行つて誤を防いだ. 
注 射の場 所：家鬼耳政靜脈.

注 射の速度：注射すべき全量を常に正確に $30 \mathrm{~s}$ 間で注入した. 注射の速度も亦刍性死の發生 に重大な影響があるものだから(町 2 )) 之は常に一定する必要がある.家鬼では血液の 1 循環に要寸 る最短時間は $7,5 \mathrm{~s}$, 收均時間は $15 \mathrm{~s}$ であると云ふが(加藤 ‘)) $15 \mathrm{~s}$ では少しの手違も大きい差異を來すか ら余は此の値に近く目.つ正確に行ひ搨い點で 30s を注入時間と定めたのである.

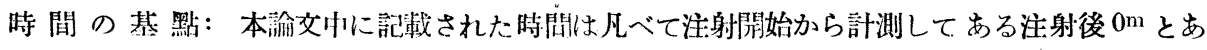
るは凡べて注射門始から後の時間である.

\section{b. Kolloid-銀對 kg 0,16 g を濃度を異にして注射した實驗}

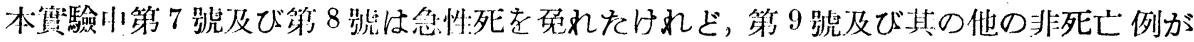
10 少至 $15^{\mathrm{m}}$ 後には必和乎吸困難が潗火するのに反してての第 7 號及び第, 8 號は $30^{\mathrm{m}}$ 後に

第 1 衰. $2 \%$ Kolloid-銀對 $\mathrm{kg} 8 \mathrm{cc}$.

\begin{tabular}{|c|c|c|c|c|}
\hline 動 物 番 號 & 體 重 性 別 & 注射量 (cc) & 轉 & 歸 \\
\hline 1 & $2100 \mathrm{~g}$ & 17,0 & 死 & $5^{\mathrm{m}} 30 \mathrm{~s}$ \\
\hline 2 & $1850 \mathrm{~g}$ & 15,0 & 死 & $5^{\mathrm{m}} 30 \mathrm{~s}$ \\
\hline 3 & $1920 \mathrm{~g}$ & 15,0 & 死 & $6 \mathrm{~m} 30 \mathrm{~s}$ \\
\hline 4 & $1850 \mathrm{~g}$ & 14,5 & 死 & $4^{\mathrm{m}} 40^{\mathrm{s}}$ \\
\hline
\end{tabular}

（註）本表及び以下の各表に見られる時間的記载は沬射より呼吸の完全停止に至る゙までの時閐在示す。

第 2 表. $8 / 3 \%$ Kolloir-銀對 $\mathrm{kg} 6$ cc.

\begin{tabular}{|c|c|c|c|c|}
\hline 動 物 番 號 & 體 盄 性 別 & 注射量 (cc) & 轉 & 歸 \\
\hline 5 & $2220 \mathrm{~g}$ & 13,5 & 死 & $4^{\mathrm{m}} 30^{\mathrm{s}}$ \\
\hline 6 & $1850 \mathrm{~g}$ & 11,0 & 死 & $3 \mathrm{~m} \mathrm{30s}$ \\
\hline 7 & $2080 \mathrm{~g}$ & 12,5 & 生 & \\
\hline 8 & $2100 \mathrm{~g}$ & 12,5 & 生 & \\
\hline 9 & $2000 \mathrm{~g}$ & 12,0 & 生 & \\
\hline
\end{tabular}

至つても呼吸困雖が相變ら想激しかつたから撲殺して解剖した處，右心室に小亘大の凝血 を認めを點，やはり他の非死じ例と注異つて扂た，恐らく辛ふじて死を免れたるのであらう

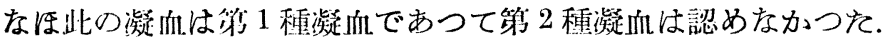

第 3 表. $4 \%$ Kolloid-銀對 $\mathrm{kg} 4 \mathrm{cc}$.

\begin{tabular}{|c|c|c|c|c|}
\hline 動 物 番 號 & 體 重 性 別 & 注射量 (cc) & 轉 & 歸 \\
\hline 10 & $2500 \mathrm{~g}$ & 10,0 & 生 & \\
\hline 11 & $1850 \mathrm{~g}$ & 7,5 & 生 & \\
\hline 12 & $2080 \mathrm{~g}$ & 8,5 & 生 & \\
\hline 13 & $1850 \mathrm{~g}$ & 7,5 & 生 & \\
\hline
\end{tabular}




\section{c. Kolloid-銀溶液對 $\mathrm{kg} 2 \mathrm{cc}$ を澧度を異にして注射した貫驗}

第 4 表. $8 \%$ Kolloid-銀對 $\mathrm{kg} 2$ cc.

\begin{tabular}{|c|c|c|c|c|}
\hline 動 物 番 號 & 體 重 性 別 & 注射量 (cc) & 轉 & 歸 \\
\hline 14 & $1850 \mathrm{~g}$ 우 & 3,7 & 生 & \\
\hline 15 & $1900 \mathrm{~g}$ & 3,8 & 生 & \\
\hline 16 & $2150 \mathrm{~g}$ & 4,5 & 生 & \\
\hline 17 & $1950 \mathrm{~g} \quad \delta$ & 4,0 & 生 & \\
\hline
\end{tabular}

第 5 表. $12 \%$ Kolloid-銀對 $\mathrm{kg} 2 \mathrm{cc}$.

\begin{tabular}{|c|c|c|c|c|}
\hline 動 物 番 號 & 體 重 性 別 & 注射量 (cc) & 轉 & 躘 \\
\hline 18 & $2060 \mathrm{~g}$ 우 & 4,1 & 生 & \\
\hline 19 & $1940 \mathrm{~g} \quad \hat{o}$ & 3,9 & 生 & \\
\hline 20 & $1880 \mathrm{~g}$ 우 & 3,8 & 生 & \\
\hline 21 & $1950 \mathrm{~g}$ ㅇํㅇ & 3,9 & 生 & \\
\hline
\end{tabular}

第 6 表. $20 \%$ Kolloid-銀對 $\mathrm{kg} 2 \mathrm{cc}$.

\begin{tabular}{|c|c|c|c|c|}
\hline 動 物 番 號 & 體重 性別 & 法射量 (cc) & 轉 & 歸 \\
\hline 22 & $1870 \mathrm{~g}$ & 3,7 & 死 & $7 \cdots 30 \mathrm{~s}$ \\
\hline 23 & $2050 \mathrm{~g}$ & 4,1 & 生 & \\
\hline 24 & $2200 \mathrm{~g}$ & 4,4 & 生 & \\
\hline 25 & $1820 \mathrm{~g}$ & 3,6 & 死 & $4^{\mathrm{m}} 10 \mathrm{~s}$ \\
\hline 26 & $2000 \mathrm{~g}$ & 4,0 & 生 & \\
\hline
\end{tabular}

第 7 表. $30 \%$ Kolloid-銀對 $\mathrm{kg} 2$ cc.

\begin{tabular}{|c|c|c|c|c|}
\hline 動 物 番 號 & 體 重 性 別 & 注射量 (cc) & 轉 & 䜷 \\
\hline 27 & $1900 \mathrm{~g}$ & 3,8 & 死 & $5^{\mathrm{m}}$ \\
\hline 28 & $1900 \mathrm{~g}$ & 3,8 & 死 & $6 \cdots 10^{\prime}$ \\
\hline 29 & $1960 \mathrm{~g}$ & 3,9 & 死 & $6^{\prime \prime \prime}$ \\
\hline 30 & $2750 \mathrm{~g}$ & 5,5 & 死 & $8 \mathrm{~m} 30 \mathrm{~s}$ \\
\hline
\end{tabular}
c. 小
括

以上の實驗成績を一括して表觖すれば第 8 表となる。 


\begin{tabular}{|c|c|c|c|c|c|c|c|}
\hline \multirow{2}{*}{ 群 } & \multirow{2}{*}{ 番 } & \multirow{2}{*}{ 號 } & \multirow{2}{*}{ 注 射 量 } & \multicolumn{2}{|c|}{ Kolloid-銀量對 kg } & 轉 & 歸 \\
\hline & & & & 絕對量 $(\mathrm{g})$ & 容量 (cc) & 生 & 死 \\
\hline 第 & 1 & 群 & $2 \% \times 8 \mathrm{cc}$ & 0,16 & 8 & 0 & 4 \\
\hline 第 & 2 & 群 & $8 / 3 \% \times 6 c c$ & 0,16 & 6 & 3 & 2 \\
\hline 第 & 3 & 群 & $4 \% \times 4 \mathrm{cc}$ & 0,16 & 4 & 4 & 0 \\
\hline 第 & 4 & 群 & $8 \% \times 2 \mathrm{cc}$ & 0,16 & 2 & 4 & 0 \\
\hline 第 & 5 & 群 & $12 \% \times 2 \mathrm{cc}$ & 0,24 & 2 & 4 & 0 \\
\hline 第 & 6 & 群 & $20 \% \times 2 \mathrm{cc}$ & 0,40 & 2 & 3 & 2 \\
\hline 第 & 7 & 群 & $30 \% \times 2 \mathrm{cc}$ & 0,60 & 2 & 0 & 4 \\
\hline
\end{tabular}

第 8 表に於て明らかな㥞て或る範国內では濃度が大となれば急性死を來しにくい. 殊

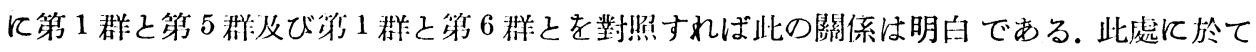
Messini が硫黃-Sol 飞就て澄明した處の濃度と致死作用との關係は Kolloid-銀 "櫻木”、於 ても亦存在する执か澄明せられた。

\section{3. 膠啠溶液の㓡透壓の見地から行つた賽驗}

前章の售驗より Kolloid-銀溶液の致死作用に對して其の濃度が重大な影響を及生す事 而も稀釋によつて毒性を增す事が認められた。然らば此の現象の本質は何であららか.膠質

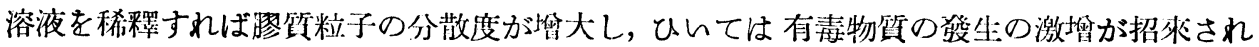
ると云ふＭessini の見解に就ては本篇第 1 章に於て述べる所があつた. 然しながら前篇第 4 章b (Kolloid-Schock の分颣) 飞於て觸れて㯰いた樣に Schock-症狀の强弱が必和しも急性 死䋁生の有無に亚行しないのみなら和時には却つて端行する樣に見える場合るある. 從つ て若しSchock-症狀が: Kolloid-銀の藥理作用の結果である己すれば急性死の發生を單純汒

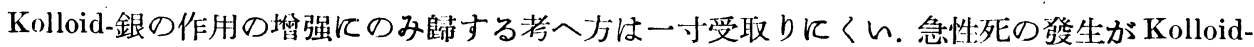
銀の藥理作用と云ふ單一の原因に依ると考へるよりは, 此の作用の外飞更に別筒の因子が 存在して虞て, 之が加はるか否かによつて急性死の發生が店右されると考へる方が、上り實 狀に即しては居るまいか。此處て於て余の興味を起したのは膠質溶液の滲透壓の特異性で

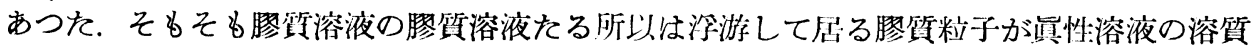
粒子に比して著しく大きいと云ふ事である. 之に依つて膠質の存在は溶媒の渗透壓に殆ぎ

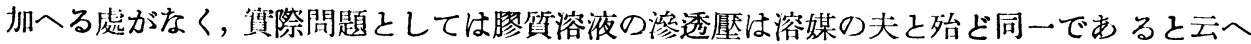
るのである(加藤 $\left.{ }^{5}\right)$ ). 從つて蒸餾水を溶媒ととするKolloid-銀溶液を静脈內に注入するに當 つては膠質粒于本來の藥理作用の外に蒸餾水の如き低滲透壓液の靜脈內注入による影響も 亦考虑沉入る必要があらう。そして稀釋による致死作用の增大が後者に關係して居る事 はあるまいか。 


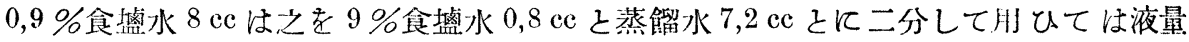
及び食塩の絕對量に於ては變化がないが滲透壓の立場からは多少の考虑を要するだらう。

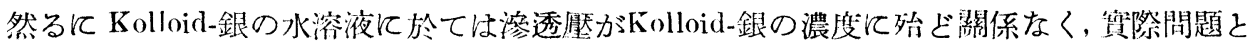

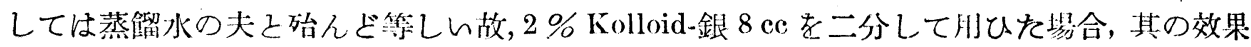

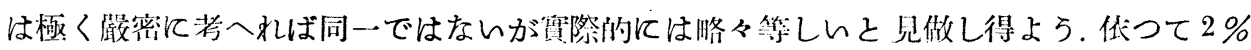

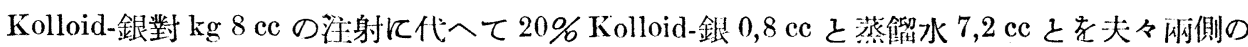

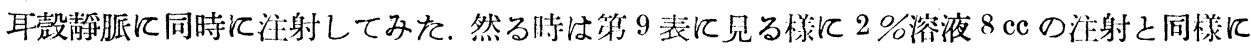
定型的の急性死を見た．此の際 $2 \%$ Kolloid-銀溶液と $20 \%$ 溶液とでは Messini の ふ榚に 膠貎粒子の分散度は異る箱であるが，本賽驗の成䋶から判斷すれば夫は死亡率を在右する 飞足らない事が一見して明白である。故と Messini の强調する栐な分散度の關係は少くとる

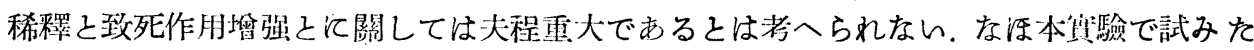

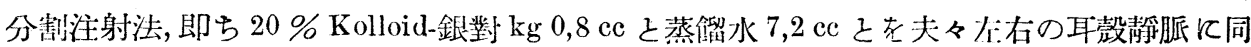
時に注射する方法は以下の諸鿓驗の土臺となるものであつて此の潦馏水 $7,2 \mathrm{ce}$ の代りに色

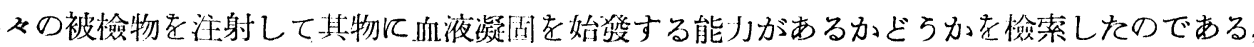

\begin{tabular}{|c|c|c|c|c|c|c|}
\hline \multirow{2}{*}{ 動物番號 } & \multirow{2}{*}{\multicolumn{2}{|c|}{ 體 重 性別 }} & \multicolumn{2}{|c|}{ 注 射 量 cc } & \multirow{2}{*}{ 轉 } & \multirow{2}{*}{ 歸 } \\
\hline & & & $20 \%$ Kolloid-銀 & 蒸 餾 水 & & \\
\hline 31 & $1800 \mathrm{~g}$ & $\hat{o}$ & 1,45 & 13,0 & 死 & $7 \mathrm{~m}$ \\
\hline 32 & $1920 \mathrm{~g}$ & $\hat{\jmath}$ & 1,5 & 13,5 & 死 & $6^{m}$ \\
\hline 33 & $1900 \mathrm{~g}$ & 우 & 1,5 & 12,5 & 死 & $6 \mathrm{~m} 30 \mathrm{~s}$ \\
\hline 34 & $1760 \mathrm{~g}$ & 우 & 1,4 & 13,5 & 死 & $7 m$ \\
\hline
\end{tabular}

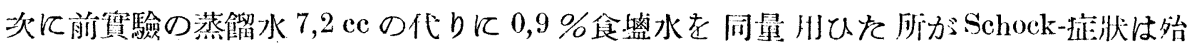
ビ同程度に强いがんづれも死亡ぜ゙ 10-15 $\mathrm{m}$ 以队に Schock より恢復した。 其の成績は第 10 表に見る通りである。

\begin{tabular}{|c|c|c|c|c|}
\hline \multirow{2}{*}{ 動物番號 } & \multirow{2}{*}{ 體 重 性 別 } & 鿊 射 量 cc & \multirow{2}{*}{ 轉 } & \multirow{2}{*}{ 歸 } \\
\hline & & 0,9 \% 食热水 & & \\
\hline 35 & $2270 \mathrm{~g}$ & 17,0 & 少: & \\
\hline 36 & $1880 \mathrm{~g}$ & 14,0 & 生 & \\
\hline 37 & $1900 \mathrm{~g}$ & 13,5 & 生 & \\
\hline 38 & $1970 \mathrm{~g}$ & 14,0 & 生 & \\
\hline
\end{tabular}

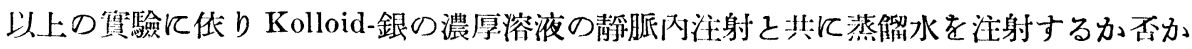

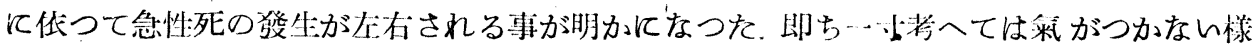


な蒸䬫水の注射が急性死の發生には案外重大關係のある事が判明したのである. 從つて又 蒸餾水を溶媒己する稀薄 Kolloid-銀溶液の靜脈內注射飞よる急性死の發生に於て子該溶液

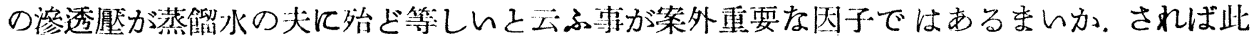
の點を更に確める䳩に今度は $0,9 \%$ 食塧水を溶媒とした $4 \%$ Kolloid-銀溶液を調製して之

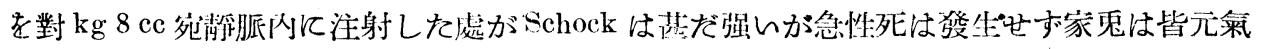

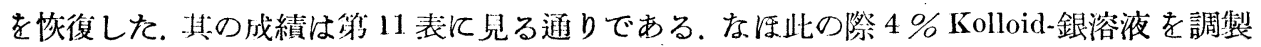
するには $8 \%$ Kolloid-銀溶液と $1,8 \%$ 食壏水とを作り, 使用前夫らの同量を探つて混合し た.

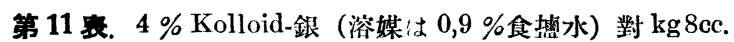

\begin{tabular}{|c|c|c|c|c|}
\hline 動 物 番 號 & 體 事 性 別 & 注 射 量 cc & 轉 & 歸 \\
\hline 39 & $2000 \mathrm{~g}$ & 16,0 & 生 & \\
\hline 40 & $1900 \mathrm{~g}$ & 15,0 & 生 & \\
\hline 41 & $1850 \mathrm{~g}$ & 15,0 & 生 & \\
\hline 42 & $1980 \mathrm{~g}$ & 16,0 & 生 & \\
\hline
\end{tabular}

以上の三赛驗より Kolloid-銀溶液の溶媒が蒸餾水である事が致死作用の重大な因子で

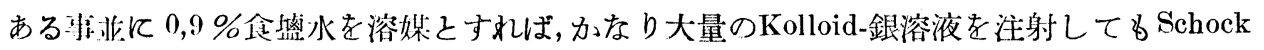
を起すのみで念州:死を來さない事を碓認した。

\section{4. 血小板の破瞔が急性死の發生を誘發する一因子となるか}

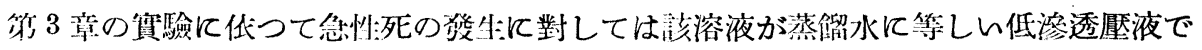
ある执が更要な一网子である才が登明せられた。然らば此の際其の低渗透壓性によつて如

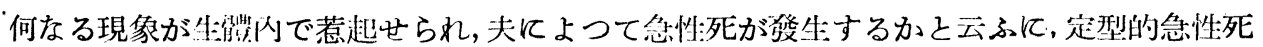
に於て最も吾人の注意を惹く所胃は血管內血液凝周現像であつて，之が直接の死因子認め

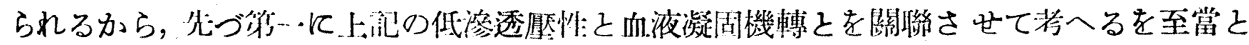

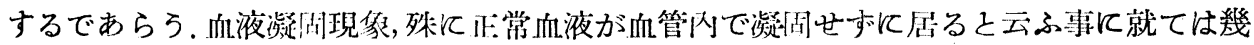
多の研究が箴され從つて其の研觉に基いて多くの學說が立てられて居るが，未だ其の袎轉

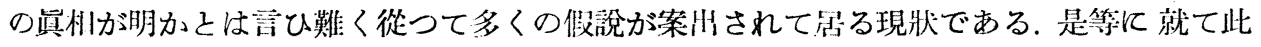

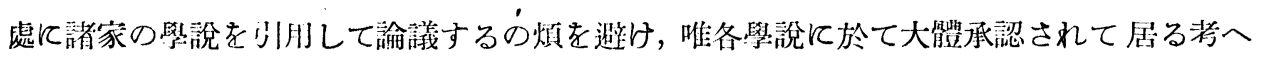
方として先づ何らかの原因により組織液入は血液倠形成分中に含有せられて居る所の Thrombokinase なるものが逝離して血獎怩飞饰存する非働性のProthrombin を賦活する事 から血液凝闲が始设すると云ふ而を指摘するに止める。

而して循噮血液小では Thrombokinase の保持者文は供給者として先づ第一番に血小板 
が擧げられて居る. 白血球に就ても亦同じくThrombokinase の存在が證明されて居る. 之 に反して赤血球に就ては之も有形成分の一つだからと云ふ程度に輕く考へられて居るに

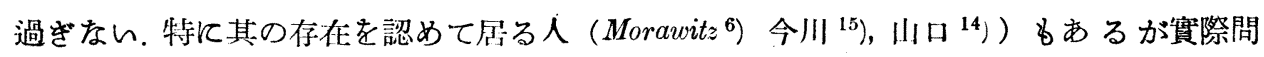
題としては一般に大して重要視されて居ないと云ふのが寒狀である. 即ち常識的には Thrombokinase こ玄へば直ちと血小板を稵想するのである.

故に余も亦先づ Kolloid-銀溶液の低渗透瓷性により循環血液山の血小板が障㶳せられ てThrombokinase が放出せられ之によつて血管內血液凝固が招來されるのではあるまいか その想定の下に, 前章の分割注射法, 即ち $20 \%$ Kolloid-銀對 $\mathrm{kg} 0,8 \mathrm{cc}$ 乙蒸鲲水 7,2 cc との同

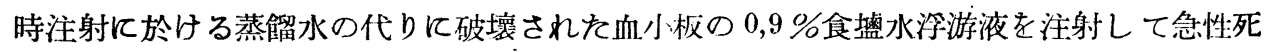
の發生如何を實驗した。即ち健康家鬼の頸動脈を露出し, $3,8 \%$ 构榅酸曹達溶液を容れ置い た注射器を以て枸椽酸曹遵溶液 1 容量己血液 8 容量とが混合する样に採血する. 而して此 の $8 / 9$ 构檴酸血（全量中に $8 / 9$ 容量の血液を含们するので斯く言ふ）より Fonio ${ }^{7}$ )の法によ つて出來る大け充分に血小板を分離する. 即ち此の构緣酸血を 2000 回 $7^{\mathrm{m}}$ 倳心沈澱し上層 ，の强く混濁した血小板含有血漿を他の沈澱管に移し，殘りのものに $0,9 \%$ 食盐水を加へて 振り再び前と同樣の遠心沈澱を行ひ白濁した上層を先の血小栊含们血漿飞加人，之を 2500 -3000回 $1^{\mathrm{h}}$ 乃至 $1^{\mathrm{h}} 30^{\mathrm{m}}$ 間遠心沈澱して上層が完全に透明となつた後, 血小板の沈渣を瑪 瑙の乳鉢に移して充分に研磨する. 乙に蒸餾水 $5 \mathrm{cc}$ を加へて車に侀際した後, 之を 30--60

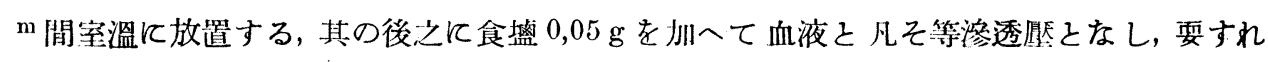
ば $0,9 \%$ 食塩水を加へて採血量の $1 / 4$ 容量とする. 然る時は此の破壞された血小板の浮游液 $5 \mathrm{cc}$ は血液 $20 \mathrm{cc}$ 中の血小板量に近似量の血小板を含行して居る事之なる. 紋に於て前章の 分割注射法に於ける蒸餾水對 $\mathrm{kg}$ 7,2 cc の代りに前記の血小板浮游液對 $k g 5 \mathrm{ce}$ を用ひて, 20

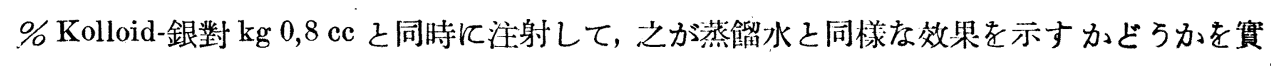
驗した. 然るに余の期待に反して Schock-症狀圭呈するのみで急性死を來す事はない. 其の 成績は第 12 表に記した通りである.

第 12 表. 破壞血小板浮游液對 $\mathrm{kg} 5 \mathrm{cc}$ と $20 \%$ Kolloid-銀對 $\mathrm{kg} 0,8 \mathrm{cc}$ との同時注射.

\begin{tabular}{|c|c|c|c|c|c|}
\hline \multirow{2}{*}{ '動物番號 } & \multirow{2}{*}{ 體 重 性 別 } & \multicolumn{2}{|c|}{ 注 射 量 ce } & \multirow{2}{*}{ 轉 } & \multirow{2}{*}{ 歸 } \\
\hline & & $20 \%$ Kolloid-銀 & $\begin{array}{l}\text { 破畩血小板 } \\
\text { 浮 游 液 }\end{array}$ & & \\
\hline 43 & $2300 \mathrm{~g}$ & 1,85 & 12,0 & 生 & \\
\hline 44 & $1920 \mathrm{~g}$ & 1,5 & 10,0 & 生 & \\
\hline 45 & $2250 \mathrm{~g}$, ㅇ & 1,8 & 12,0 & 生 & \\
\hline 46 & $2000 \mathrm{~g}$ & 1,6 & 10,0 & 生 & \\
\hline
\end{tabular}

此の際對 $\mathrm{kg} 5 \mathrm{cc}$ の血小板浮游液, 之を換算すれば血液 $20 \mathrm{cc}$ 中の血小板の破壞された ものが Kolloid- 銀と共働して血管內血液凝固を來し得ないと云ふ事は極めて注目すべき事 
實であつて，對 $\mathrm{kg} 20 \mathrm{cc}$ の血液と云へば家鬼の全血量の約 $1 / 3$ 飞相當する大量である事を 考へ合せる時, 果して血小板は Thrombokinase の供給者として夫程重要視すべきるの名何

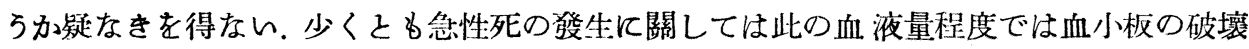
が起つても起らなくでも大した問題ではないるのと思はれる.

\section{5. 赤血球の破壞が急性死の墢生を誘發する一因子となるか}

前章の實驗により破壞せられた血小板の浮游液は可なりの大量を $20 \%$ Kolloid-銀對 $\mathrm{kg} 0,8 \mathrm{cc}$ 乙共飞注射しても血管內血液凝固を起して急性死を來寸能力のない事が明白とな つた. 然らば赤血球の破壞されたものはどうか. 余は次の如くにして實驗した.

即ち $8 / 9$ 构濑酸血 $18 \mathrm{cc}$ (原血液として $16 \mathrm{cc}$ ) を取り之を 2000 回 $7^{\mathrm{m}}$ 遠心沈澱して上

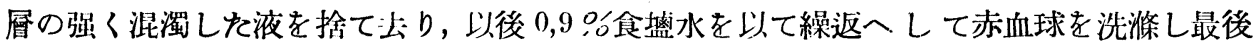
の沈渣の上面に血小板又は白血球の白層を認めない㥞になつた後, 之に蒸餾水 $20 \mathrm{cc}$ 加 へて室溫に $30^{\mathrm{m}}$ 少至 $1^{\mathrm{h}}$ 放通して完全に溶血させる. 此の溶血液に $0,2 \mathrm{~g}$ の食盐を加へて血

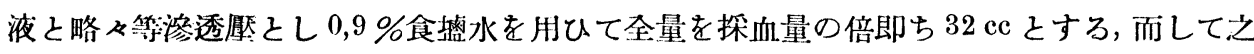
を $50 \%$ 溶解赤血球液乙呼ふ. 從つて此の液 $1 \mathrm{cc}$ は原血液 $0,5 \mathrm{cc}$ 中の赤血球か溶解したもの に相傢する.

第 3 章の分制注射法に於ける蒸䬰水對 $\mathrm{kg} 7,2 \mathrm{cc}$ 代りに此の溶解赤血球液を用ひて 20 \% Kolloid-銀溶液對 $\mathrm{kg} 0,8 \mathrm{cc}$ 己同時に注射すれば常に急性死を來した. 依つて此の溶解赤

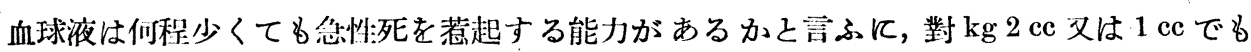
定型的急性死を起し得た。其の成緽は第 13 表及び第 14 表に見る通りである.

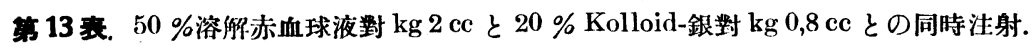

\begin{tabular}{|c|c|c|c|c|c|c|}
\hline \multirow{2}{*}{ 動物番號 } & \multirow{2}{*}{\multicolumn{2}{|c|}{ 體重 性別 }} & \multicolumn{2}{|c|}{ 注 射 量 cc } & \multirow{2}{*}{ 轉 } & \multirow{2}{*}{ 歸 } \\
\hline & & & $20 \%$ Kolloid-銀 & 溶解赤血球液 & & \\
\hline 47 & $1830 \mathrm{~g}$ & $\delta$ & 1,45 & 3,4 & 死 & $4^{m}$ \\
\hline 48 & $1980 \mathrm{~g}$ & $\delta$ & 1,6 & 3,9 & 死 & $3^{\mathrm{m}} 30 \mathrm{~s}$ \\
\hline 49 & $2000 \mathrm{~g}$ & 우 & 1,6 & 4,0 & 死 & $2^{\mathrm{m}}$ \\
\hline 50 & $2200 \mathrm{~g}$ & 우 & 1,75 & 4,4 & 死 & $3^{\mathrm{m}}$ \\
\hline
\end{tabular}

本表の全例は痤攣の㷋來急激で唗狀激起であつた。 
第 14 表. 50 \%溶解赤血球液對 $\mathrm{kg} 1 \mathrm{cc}$ 子 $20 \%$ Kolloid-銀對 $\mathrm{kg} 0,8$ との同時注射.

\begin{tabular}{|c|c|c|c|c|c|c|}
\hline \multirow{2}{*}{ 動物番號 } & \multirow{2}{*}{ 體 重 } & \multirow{2}{*}{ 性 別 } & \multicolumn{2}{|c|}{ 沙 射 量 cc } & \multirow{2}{*}{ 轉 } & \multirow{2}{*}{ 歸 } \\
\hline & & & $20 \%$ Kolloid-銀 & 溶解赤血球液 & & \\
\hline 51 & $2200 \mathrm{~g}$ & $\hat{\delta}$ & 1,75 & 2,2 & 死 & $7 \mathrm{~m}$ \\
\hline 52 & $2120 \mathrm{~g}$ & 우 & 1,7 & 2,1 & 死 & $2^{m 30 s}$ \\
\hline 53 & $2000 \mathrm{~g}$ & $\delta$ & 1,6 & 2,0 & 死 & $8^{m}$ \\
\hline 54 & $1850 \mathrm{~g}$ & $\hat{\delta}$ & 1,5 & 1,85 & 生 & \\
\hline 55 & $2550 \mathrm{~g}$ & 우 & 2,0 & 2,6 & 死 & $5 \mathrm{~m} 30 \mathrm{~s}$ \\
\hline
\end{tabular}

本表第 54 號は急性死を忽れたが $40^{\mathrm{m}}$ 後に至つても運動せず, 呼吸困難 8 去らない. $1^{\mathrm{h}}$ 後に擈殺したらば右心宗に大量大の凝血があつた。他の部分には凝血を認めなかつたが辛 ふじて死を免れたるのと思はれる。

以上の樣に余の最初の期待に反して破垻されを血小板の浮游液ば之を Kolloid-銀と共 に注射しても血管內血液凝固を發生しないのに, 赤血球は僅に對 $\operatorname{kg} 0,5$ J至 $1 \mathrm{cc}$ の血液相 當量が溶解した丈で血管內血液凝固を發生し，鱼州死を惹起すると云ふ成績を得た。

此處に示された血小板之赤血球との能力の比洨, 即ち $20 \mathrm{cc}$ の血液怆血小板はThrom-

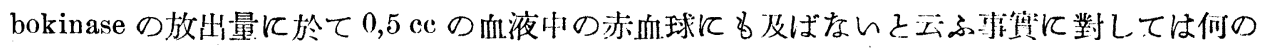
樣な解釋を下したらよいであらうか. 然るに最近 Scheuring ${ }^{8}$ ) は菬だ興味ある研究を弡表し て居た。 即ち氏は Novhirudin-血又は Novhirudin-血漿を慗示藥の如くに使用して Thrombokinase 量を推算する方法により赤血球のThrombokinase 量を例究した。乙して其の結

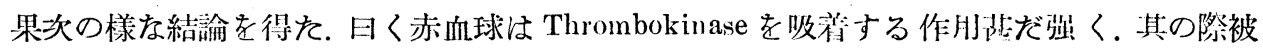
吸着物質は主として礎質中に集中せられる. 而して此の性濆があるので赤血球は循環血液 中で Thrombokinase の爲に水量調節池の栐な意味を们し適掌量の Thrombokinaseを放出し て血液の凝固力を調節する作用があるらしいと. 又赤血球は Thrombokinase の保住者とし ては血小板や白血球等より遙が重視せらるべきであると.氏は更に Nolf て血小板は Thrombokinase の供給者としては意義少きものであると霄つで居る.

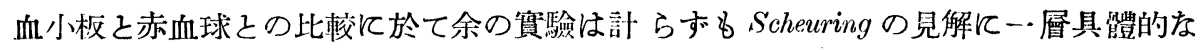
證據を提供する事となつた。 又逆に氏の研究壮余の得た實驗成績に们力なる文持を與へて 居る.而して此の事實たるや血液凝固の理解て對して齿だ重大な影響を與へるもので, 䐆來 血液凝固機轉, 殊に所謂Thrombokinase の抙離機轉に關して粥しい視野を開くるのである と信ずる.

\section{6. 蒸餾水對 kg 7,2 cc の靜眽内注射で何程の溶血が意起されるか}

前章の實驗により第 3 章の分割注射法即ち $20 \%$ Kolloid-銀 $0,8 \mathrm{cc}$ と蒸餾水 $7,2 \mathrm{cc}$ との 


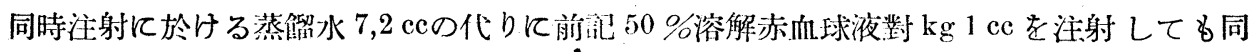

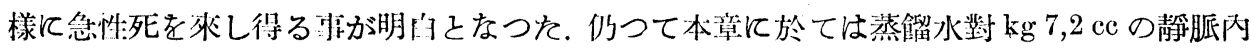
注射によつて溶血が起るか。，起るものとすれば其の程度は前章の賽驗成績と照合して血管

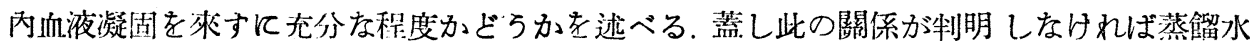
の注射の效果己溶解赤血球液の注射の效果己は必亦しる同一視出來ないからである.

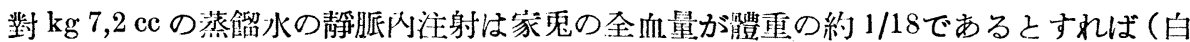

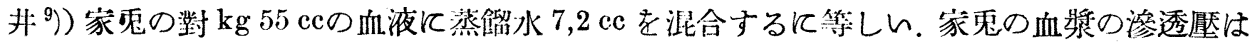

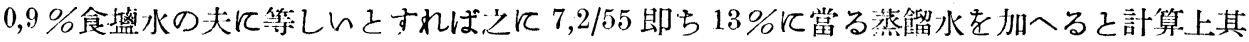

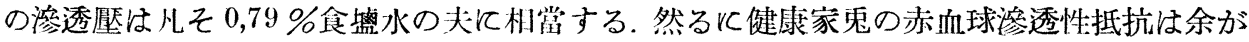
測定した所によるも最小抵抗 $0,52 \%$ あつて $0,78 \%$ では全く溶血を見ないのである. 然し ながら蒸餾水が注射されて完全に沘合され終つて後は上記の滲透壓となり溶血は起さない

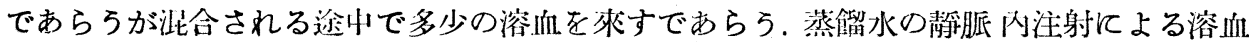

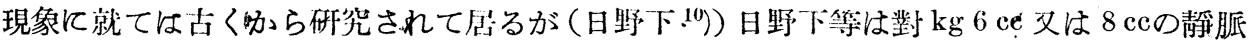
內注射による溶血量の测定を試みて虑る。然し氏等の政究の目的及び賽驗佟件は余の夫と

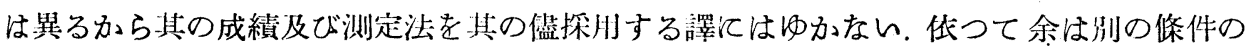
下で测定を試みた。

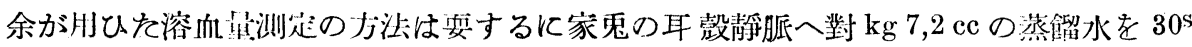

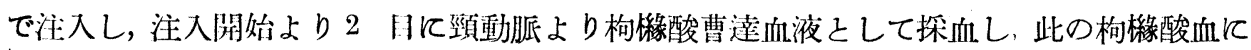

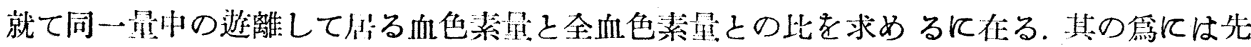

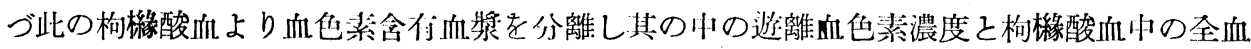
色素濃度とをDubrqque の比色計で比較し，北の濃度比率を土臺として更に溶血した赤血球 量の全赤血球组几對する百分率を推算すればよん,勿論此の際注射より採血迄の $2^{\mathrm{m}}$ 間に遊 離した血色素の一蔀は㨁ちに網状織內被細胞系によつて攝取せられ循噮血液中より消失し

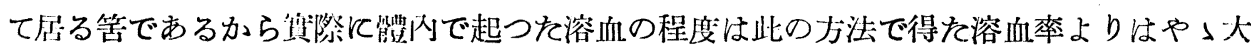
きいであらう.賽施汇賞つて次の樣な考虑を加へた。即ち血色素の濃度を比色に適當ならし

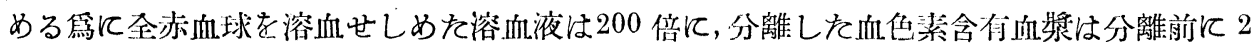
倍に稀釋した，又此の血獎は血小板其の他の浮游物により混濁して居ては比色に當つて障 害を來すから强い邀心沈涮によつて之らを除去して透明ならしめる必要がある（本章末尾 註公髙)

其の方法を具腈的に述べれば先づ $0,3 \mathrm{~g}$ 位の食盐を容れた Kolben 乙蒸餾水 $195 \mathrm{cc}$ を容

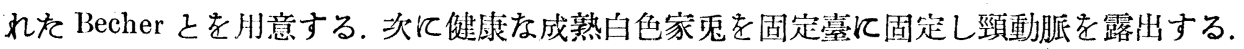

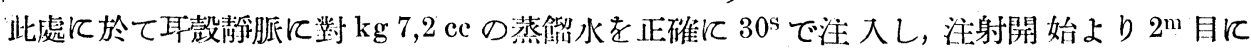

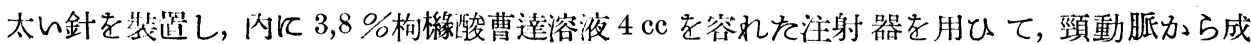




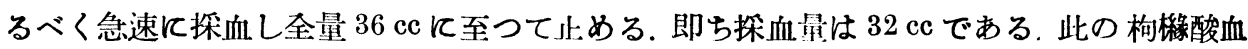

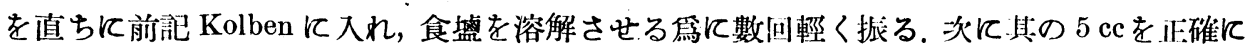
Becher 飞加へ溶血と同時に 40 倍に稀釋する. 完全に溶血が起つた後更に其の一部を蒸溉 水を以て正しく5 倍すれば此の全赤血球の溶解した溶血液は 200 倍せられてある. 此の全 血色素含有溶血液の濃度をI とする，次に Kolben に殘つて局る构䋇酸血の一部を $0,9 \%$ 食

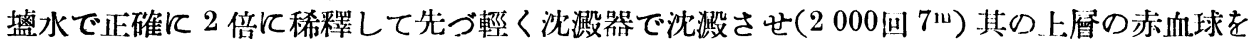

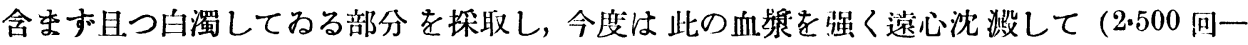
3000 回 $1^{\mathrm{h}} 30^{\mathrm{m}}$ 間）透明にならしめる. 此の血漿の血色素濃度を II とする. 此等の血色素溶 液に夫々一酸化炭素を充分に通じて其の中の血色素を完全に酸化炭素-Hämoglobin と化し 之をDubosque の比色計で比較する。

斯くの如き方法で得た血色素濃度比率（2×II / $200 \times$ I ) は第 15 表 A 及び Br示す如 くである.

芽 15 衰. A. 雄 鬼.

\begin{tabular}{|c|c|c|c|c|c|}
\hline 動物番號 & 月 日 & 室 溫 & 體 & 蒸䬯 水 cc & 濃 度比 \\
\hline 56 & $1 / \mathrm{IX}$ & $23^{\circ} \mathrm{C}$ & $2000 \mathrm{~g} \hat{\delta}$ & 14,5 & 1,3 \\
\hline 57 & $2 / \mathrm{IX}$ & $22^{\circ} \mathrm{C}$ & $2000 \mathrm{~g}$ s & 14,5 & 1,3 \\
\hline 58 & $3 / I X$ & $26^{\circ} \mathrm{C}$ & $1900 \mathrm{~g} \delta$ & 13,5 & 1,4 \\
\hline .59 & $5 / \mathrm{IX}$ & $24^{\circ} \mathrm{C}$ & $2150 \mathrm{~g} \delta$ & 15,5 & 1,3 \\
\hline 60 & $6 / \mathrm{IX}$ & $30^{\circ} \mathrm{C}$ & $2500 \mathrm{~g}$ o & 18,0 & 1,4 \\
\hline \multicolumn{3}{|c|}{ 雄鬼 5 吃の平均值 } & & & $\mathbf{1 , 3 4}$ \\
\hline
\end{tabular}

䒼 15 表. B. 雌 鬼.

\begin{tabular}{|c|c|c|c|c|}
\hline 動物番號 & 月日 室溫 & 體 & 蒸 馏 水 cc & $\begin{array}{c}\text { 濃 度比 渄 } \\
\%\end{array}$ \\
\hline 61 & $27 /$ VIII $26^{\circ} \mathrm{C}$ & $2000 \mathrm{~g}$ 우 & 14,5 & 1,8 \\
\hline 62 & $28 /$ VIII $26^{\circ} \mathrm{C}$ & $2100 \mathrm{~g}$ 우 & 15,0 & 1,9 \\
\hline 63 & $29 /$ VIII $26^{\circ} \mathrm{C}$ & $1850 \mathrm{~g}$ 우 & 13,5 & 2,0 \\
\hline 64 & $6 / \mathrm{IX} \quad 30^{\circ} \mathrm{C} !$ & $2500 \mathrm{~g}$ 우 & 18,0 & 1,7 \\
\hline \multicolumn{2}{|c|}{ 雌鬼 4 飞の平均值 } & . & & 1,85 \\
\hline
\end{tabular}

此處に興味ある事は A，B 兩样夫々の間では個體差が比較的小なのに兩群相互の閒に は明かにかなりの差異があり雌鬼に於てはより多量に溶血現像が起るものと推定される事 である. 是は偶然の結果ではなく恐らくは性別て基くものであらう. 其の依つて來る所以， 或江雌雄により赤血球の渗透性抵抗に差異があるものか, 或は又此は雄よりる對 $\mathrm{kg}$ 血液 量が少いものか更に又他の原因によるものか全く不明であるが鬼も你も测定の誤差と見做 すには餘りと特徴があるので一言附記する. 
さて前䚶の比色法によつて得られた血色素の濃度比率は直ちに以て溶血率を示するの

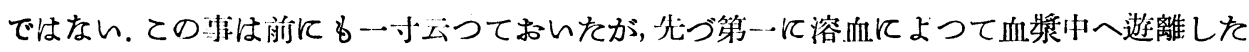
血色素のうち若干は探血時までに排泄，又は網狀織內被細胞系により攝取される等のため 飞血流中ょり消失して局る等である. 第二には溶血率を得ると汒同一容積の血液中にある 遊離血色素量と全血色素量との比率を求めればよんのであるが，前記の方法で比色の井に 供せられた血色素含们血漿は此の目们には少しく合致しない. 其の意味はその中の遊離血

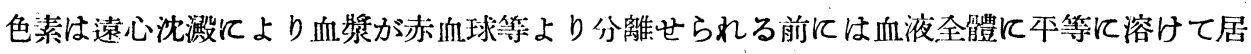
たのではなくて血液中で赤血球の占める空間には這入り込んで居なかつた，從つて其の血 色素は見かけよりる若干少的容積に溶けて居たものであるから幾分濃度が大きくなつてね る.されば第 15 表の血色絜の濃度比率汢求める溶血率よりは大きくなつてみる. 從つて之 几若干の補正を行はなりれば溶血率（同一血液中の遊離血色素量と全血色素量との比率） を示すに至らない，其の補正には先づ次の諸數值を知る事が必要である。

1）血液又は $8 / 9$ 枸槒酸血液中赤血球の占める空間の大さ。

2）血漿が高張となつた場合に赤血球より放出し得る水の量, 云ひ換へれば赤血球の 萎縮によつて血漿が增加し得る签量.

家鬼血液 $1 \mathrm{cc}$ 中の血色素量は $0,08 \mathrm{~g}$ 万至 $0,12 \mathrm{~g}$ であると云ふ(白井 ${ }^{{ }^{11}}$ )).よつて其の中

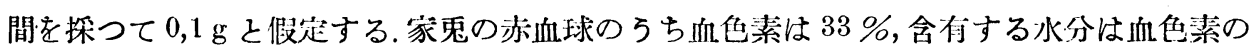
63/33 であるとすれば(Bürker $\left.{ }^{12}\right)$ ), 家鬼血液 $1 \mathrm{cc}$ 中に存する赤血球の總量は $0,3 \mathrm{~g}$, 赤血球の 含水量は $0,19 \mathrm{cc}$ となる. 赤血球の比重は 1 より大を恍ら $0,3 \mathrm{~g}$ の赤血球の容積は $0,3 \mathrm{cc}$

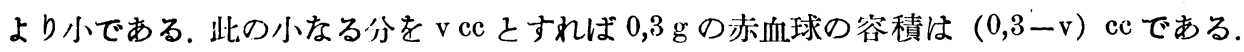
但し $0,3>v>0$

故に余が使用した $8 / 9$ 构䋇酸血 $1 \mathrm{cc}$ に對しては

1）赤血球の總容積 $(0,3-\mathrm{v}) \times \frac{8}{9}=\left(0,27-\frac{8}{9} \mathrm{v}\right) \mathrm{cc}$

2）赤血球の放出し得る水分量 $0,19 \mathrm{cc} \times \frac{8}{9}=0,17 \mathrm{cc}$

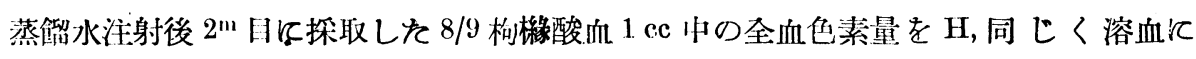

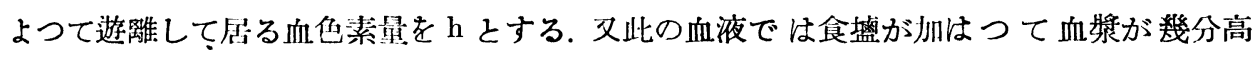
張となつて居るから赤血球は水分を放出して若干萎縮して居るものと思はれる. 此の放出 された水分量を枌格酸血 1 cc とつんて $\boldsymbol{\alpha}$ ce とすれば

$0,17>a>0$

次に比色の州に供した遊離血色素含有血漿の血色素濃度 (II) を算出しょう. 枸䋇酸 血は遠心沈澱して血永を分離する前に $0,9 \%$ 食墭水で 2 倍にうすめてあるから分離前の构 聯酸血 $1 \mathrm{cc}$ 中の赤血球總容積は $\left(0,27-\frac{8}{9} \mathrm{v}-\alpha\right) \times \frac{1}{2} \mathrm{cc}$ 
從つて其の构緣酸血 $1 \mathrm{cc}$ 中の血漿の占める容積は $\left[1-\left(0,27-\frac{8}{9} \mathrm{v}-\alpha\right) \times \frac{1}{2}\right] \mathrm{cc}$ 此の 2 倍に稀釋した构緣酸血獎 $1 \mathrm{cc}$ 中の遊離血色素量は $\frac{\mathrm{h}}{2}$. 從つて此の血漿の血色素濃 度(II)は $\frac{\mathrm{h}}{2} \times \frac{1}{1-(0,27-8 / 9 \mathrm{v}-\alpha) 1 / 2}=\frac{\mathrm{h}}{1,73+\alpha+8 / 9 \mathrm{v}}$

又完全に全血色素を溶血せしめて 200 倍に稀釋した溶血液の血色素濃度（I）は $\frac{\mathrm{H}}{200}$, 從つて第 15 表の濃度此率を q\%さすれば

$\frac{\mathrm{q}}{100}=\frac{\mathrm{II} \times 2}{\mathrm{I} \times 200}=\frac{2 \mathrm{~h}}{1,73+8 / 9 \mathrm{v}+\alpha} \times \frac{1}{\mathrm{H}}=\frac{\mathrm{h}}{\mathrm{H}} \times \frac{2}{1,73+8 / 9 \mathrm{v}+\alpha}$

$\frac{\mathrm{h}}{\mathrm{H}}=\frac{1,73+8 / 9 \mathrm{v}+\boldsymbol{\alpha}}{\mathbf{2}} \times \frac{\mathrm{q}}{100}$

第 15 表より $q=1,34$ とすれば

\section{$0,17>$ ハ $>0$ であるから}

$(1,16+0,59 \mathrm{v}) \%<\frac{\mathrm{h}}{\mathrm{H}}<\left(1,27+0,59 \mathrm{v} \%\right.$, 然ると $0,59 \mathrm{v}>0$ であるか.ら, 溶血率 $\frac{\mathrm{h}}{\mathrm{H}}$ 一は 1,16

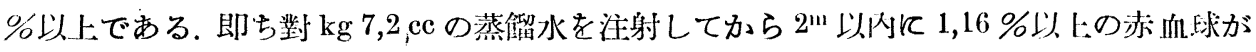

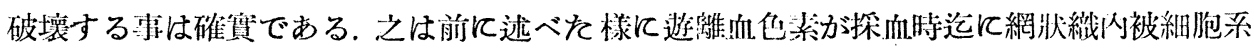
によつて血流中より若干消失してみる事を考慮に㯰いてるない計算であるから賴際は更に 幾分大きい值を示すであらう.

第 5 章の實驗に低り $20 \%$ Kolloid-銀溶 液對 $\mathrm{kg} 0,8 \mathrm{cc}$ の注射之同時に $50 \%$ 溶解赤血球 液對 $\mathrm{kg} 1 \mathrm{cc}$ 注射, 換言すれば對 $\mathrm{kg} 0,5 \mathrm{cc}$ 相當の溶血が起れば急性死が淡生する了が登明 せられて佸る. 而して對 $\mathrm{kg} 0,5 \mathrm{cc}$ の血液は全血量の $0,9 \%$ て虽る. 然るに今や對 $\mathrm{kg} 7,2 \mathrm{cc}$

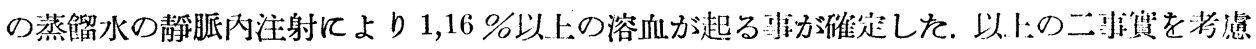

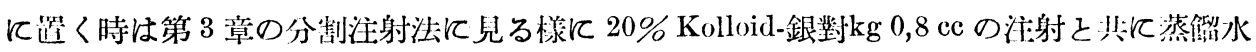

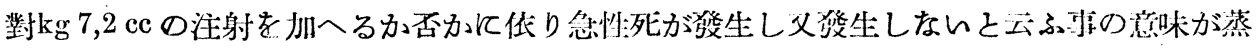
餾水注射による輕度の溶血現象の付無による之斷定し得るのである. 更に义之より推論し

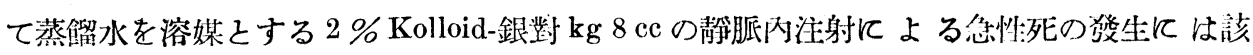

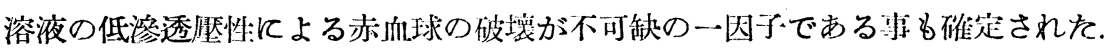

（註）此の樣に强い遠心沈激によつて血小板を充分に除去したとしても一般に血獎夫自身か滯びて居 る微かな色は除去出來ないものである. 然し其の程度のものでは此色に際して少しく注意しさへ すれば考慮に值する誤差を生ずるものでない事は余が別にモデルによつて確めた。

\section{7. 溶血現象だけで急性死が起るか}

第 5 章の賽驗沉於て濃厚な Kolloid-銀溶液の注射之闹時に 小量の赤血球の溶解が隨作 するか否がよつて急性死の成否が決定されたから，或は溶血現象だけでも柋性死が起り

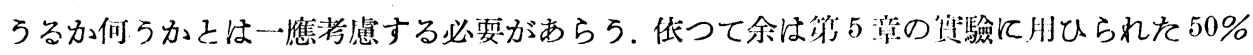

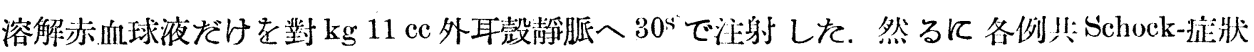


も不明嘹で $1^{\mathrm{h}}$ 以後になつても元釆である. 其の成績は第 16 表に記した. な性此の溶解赤 血球液の對 $\mathrm{kg} 11 \mathrm{cc}$ 约原血液 5,5 cc 飞當り，從つて家鬼の全血液の 1 割に相當する量であ る事注注田すべき事である。

萿 16 表. $50 \%$ 溶能赤血球液對 $\mathrm{kg} 11 \mathrm{cc}$.

\begin{tabular}{|c|c|c|c|c|}
\hline 動 物 番 號 & 體重 性別 & 注 射量 cc & 轉 & 歸 \\
\hline 61 & $2550 \mathrm{~g}$ & 28,0 & 生 & \\
\hline 62 & $2050 \mathrm{~g}$ 우 & 22,5 & 生 & \\
\hline 63 & $2300 \mathrm{~g}$ 우 & 25,0 & 生 & \\
\hline 64 & $2000 \mathrm{~g} \quad \widehat{\delta}$ & 24,0 & 生 & \\
\hline
\end{tabular}

以上の顀驗成績から見て溶血現象だけでは之が相當高度て惹起されても, 之を以て急

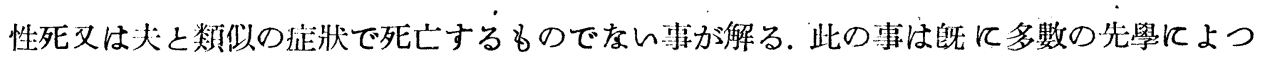
て敬察されて居る(日野下 $\left.{ }^{10}\right)$ )。汃くの如くに溶血現象だりでは急性死を來さない事は明か であるが，反對に又溶血現象を件はずに，換言すれば Kolloid 銀自身の作用だけで定型的急 性死を起す事が出來るか, 即ち又膠質溶液の低滲透壓性に基く赤血球崩 壞と云ふ現象が急

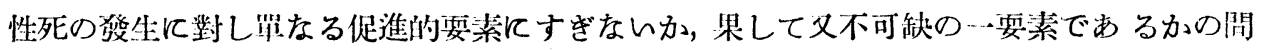
題は未解沃である. 余は此の問題に就ては Kolloid-銀の樂理作用を論ずる第 III 篇以下に 於て改めて余の賁驗成績と夫に對する余の見解とを詳しく述べる筈であるから此處では 單にKolloid-銀の作湖だりでも亦Kolloid-銀の大量を使用すれば急激な死亡を來し而も其の

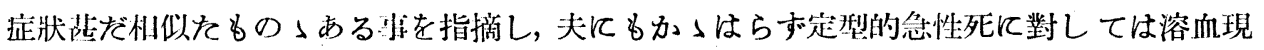
象梳不可缺の要素である事を主張するものである.

\section{Kolloid-銀自身の溶血作用は急性死の弢生に關與するか}

$20 \%$ Kolloid-銀溶液 0,8 cc の注射と同時飞 0,5 cc の血液相當量の赤血球が破裹される

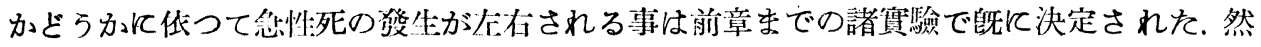
ると本鄉 $\left.{ }^{13}\right)$ らは Kollargol を $0,9 \%$ 食盐水に溶解したものに著明の溶血作用のある事を實 證して后る. Kollargol 亿於て氏らが證明した溶血作用柱 Kolloid-銀に於ても亦恐らく存在 するものと思はれる. 然る時は此の種の溶血現象は急性死の發生に對して何らかの關係を 持つて展ないか. 若し生理的食盐水を溶媒とするKolloid-銀によつて既に相當大量つ溶血現 象が起るるのとすれば, 第 5 章其の他で述べた樣に蒸餾水の注射による僅々 $1 \%$ 程度の赤 血球の破壞が左程の決定的影響を與へる事は諒解し難しからである. 敒つて余は次の樣な 實驗をした。即ち $20 \%$ Kolloid-銀溶液對 $\mathrm{kg} \mathrm{0,8} \mathrm{cc}$ の注射加ら正確に $5^{\mathrm{m}}$ おくれて前記 $50 \%$ 溶解赤血球液を對 $\mathrm{kg} 4 \mathrm{cc}$ （致死量の 4 倍）注射した。 然る處實驗動物は第 17 表に記す樣 にSchockを起すだけで急性死を起さない。 


\begin{tabular}{|c|c|c|c|c|c|c|}
\hline \multirow{2}{*}{ 動物番號 } & \multirow{2}{*}{\multicolumn{2}{|c|}{ 體 函 性 別 }} & \multicolumn{2}{|c|}{ 注 射 量 cc } & \multirow{2}{*}{ 轉 } & \multirow{2}{*}{ 蹋 } \\
\hline & & & $20 \%$ Kolloid-銀 & $\begin{array}{l}50 \% \text { 溶酰 } \\
\text { 赤血球液 }\end{array}$ & & \\
\hline 65 & $1800 \mathrm{~g}$ & 우 & 1,5 & 7,5 & 生 & \\
\hline 66 & $2300 \mathrm{~g}$ & $\hat{o}$ & 1,8 & 9,5 & 生: & \\
\hline 67 & $2200 \mathrm{~g}$ & P & 1,75 & 8,8 & 生 & \\
\hline 68 & $1950 \mathrm{~g}$ & $\delta$ & 1,55 & 7,8 & 生 & \\
\hline
\end{tabular}

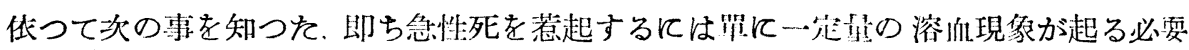
があるだけではなくて更に溶血現象が適當な時期に起る小が必要である据を，假令大量の 赤血球が破壤され夫に依つて大量のThrombokinase が遊離されるとしても其の溶血が

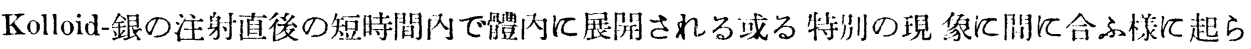

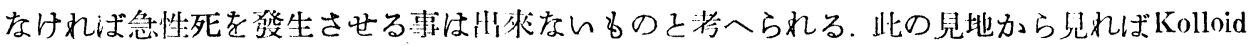

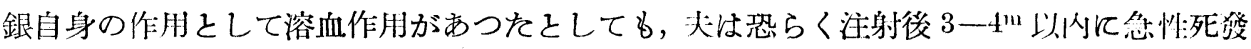
生に必要な分量に達しない鸱に，Kolloid-銀だけの注射では，よしKolloid-銀自身に溶血作 用があるとしても急性死を起さないのであらう。

\section{9. 赤血球の成分中急性死の發生に關與する物質は內漿にあるか。礎夏にあるか}

之までの賽驗により急性死の發生には赤血球內からら溶血のために或る種の血液㠜固を

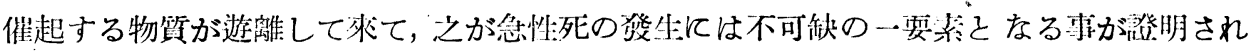

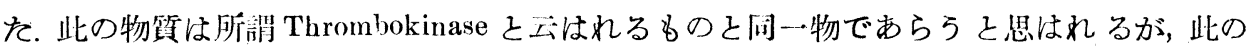

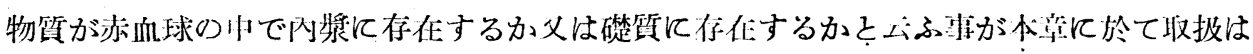
れる.

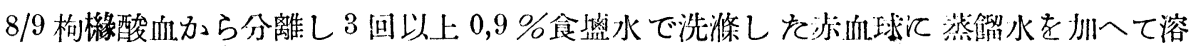

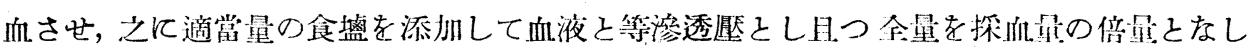

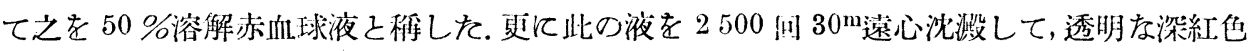
の上層液を完全に採取し之を $50 \%$ 內漿液とする。㕛礎梊は $0,9 \%$ 企盐水で何回も沙滌し最

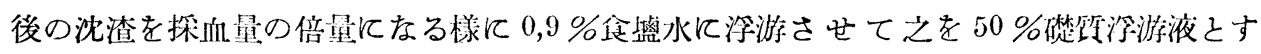

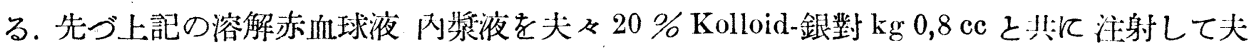
等が急性死の發生沉役立つ程度を檢索したらば冈㢡液を注射しても急性死を起し得られる のであるが，內漿液では溶解赤血球液の 4 倍量を必要とするのでるる。炏に礎啠を洗滌し て行く途中で礎質浮游液をつくり之を同㥞の注射術式で $20 \%$ Kolloid-銀對 $\mathrm{kg} 0,8 \mathrm{cc}$ と同

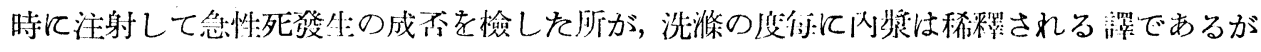
內漿が血色素の色から見てかなり稀釋されて居ても，礎質浮游液は急性死を起す能力を失 


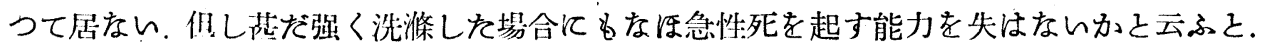
第 18 表 C、思られる栐に礎饮浮游液が血色素の色を㱠ど完全に失つをるすを注射した例 で急性死を見ない 1 例があつた。礎質を洗條するに當つては洗紧 3-4 回以後は强力な遠心

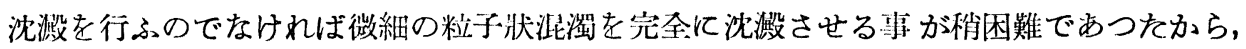

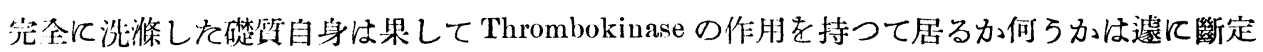

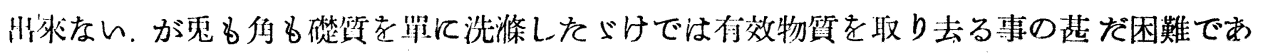
る事は碓實である，之らの成績は第18表に見られる通りである。

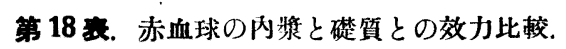

A. $19 / \mathrm{XI}$.

\begin{tabular}{|c|c|c|c|}
\hline 動 物 番 號 & 69 & 70 & 71 \\
\hline $20 \%$ Kolloid-銀 & $0,8 \mathrm{cc}$ & $0,8 \mathrm{cc}$ & $0,8 \mathrm{cc}$ \\
\hline 礎 & $0,5 \mathrm{cc}$ & & $1,0 \mathrm{cc}$ \\
\hline 队 & $0,5 \mathrm{cc}$ & $1,0 \mathrm{cc}$ & $1 / 7 \mathrm{cc}$ \\
\hline 轉 & 死 & 生 & 死 \\
\hline
\end{tabular}

B. $24 / \mathrm{XI}$.

\begin{tabular}{|c|c|c|c|c|}
\hline 動 物 番 號 & 72 & 73 & 74 & 75 \\
\hline $20 \%$ Kolloid-銀 & $0,8 \mathrm{cc}$ & $0,8 \mathrm{cc}$ & $0,8 \mathrm{cc}$ & $0,8 \mathrm{cc}$ \\
\hline 質 & $0,5 \mathrm{cc}$ & & & $1 / 4 \mathrm{cc}$ \\
\hline 墏 & $0,5 \mathrm{cc}$ & $1,0 \mathrm{cc}$ & $2,0 \mathrm{cc}$ & $1 / 15 \mathrm{cc}$ \\
\hline 触 & 死 & 生 & 死 & 死 \\
\hline
\end{tabular}

c. $24 / \mathrm{XI}$.

\begin{tabular}{|c|c|c|c|c|c|c|c|}
\hline & 號 & 76 & 77 & 78 & 79 & 80 & 81 \\
\hline \multicolumn{2}{|c|}{$20 \%$ Kolloid-銀 } & $0,8 \mathrm{cc}$ & $0,8 \mathrm{cc}$ & $0,8 \mathrm{cc}^{\circ}$ & $0,8 \mathrm{cc}$ & $0,8 \mathrm{cc}$ & $0,8 \mathrm{cc}$ \\
\hline 礎 & 犋 & $0,5 \mathrm{cc}$ & & & & $1,0 \mathrm{cc}$ & $4,0 \mathrm{cc}$ \\
\hline 队 & 獎 & $0,5 \mathrm{cc}$ & $0,5 \mathrm{cc}$ & $1,0 \mathrm{cc}$ & $2,0 \mathrm{cc}$ & $1 / 16 c c$ & $1 / 1000 \mathrm{cc}$ \\
\hline 轉 & 蹛 & 死 & 生 & 生 & 死 & 死 & 生 \\
\hline
\end{tabular}

D. $29 / \mathrm{XI}$.

\begin{tabular}{|c|c|c|c|c|c|}
\hline \multicolumn{2}{|c|}{ 動 物 番 號 } & 82 & 83 & 84 & 85 \\
\hline \multicolumn{2}{|c|}{$20 \%$ Kolloid-銀 } & $0,8 \mathrm{cc}$ & $0,8 \mathrm{cc}$ & $0,8 \mathrm{cc}$ & $0,8 \mathrm{cc}$ \\
\hline 礎 & 質 & $0,5 \mathrm{cc}$ & & $1,0 \mathrm{cc}$ & $4,0 \mathrm{cc}$ \\
\hline 队 & 獎 & $0,5 \mathrm{cc}$ & $1,0 \mathrm{cc}$ & $1 / 50 \mathrm{cc}$ & $1 / 300 \mathrm{ce}$ \\
\hline 轉 & 锓 & 死 & 生 & 生 & 死 \\
\hline
\end{tabular}


第 18 表に記した注射量は凡べて對 $\mathrm{kg}$ 量であり又礎質や內漿は凡べて原血液量て換算 してある. 又內棌の量が分數で記してある處は礎質浮游液の數回洗桬したものを使月した 場合で此の際其の浮游液の血色素て上る着色度を $50 \%$ 内漿液を基準としでと比色して, 該浮游液の血色素濃度から逆に內濌の含有量を計算しHした雼である. 此の成績によつて 吾人は赤血球成分中急性死の發生に關與する物質は內獎部にも存在するが, 礎質の部分に は更に濃厚に存在し洗條によつて之を洗ひ去る事が困踓であるから，Thrombokinase は赤 血球，殊に其の礎質に吸着せらる小性質があると公ふ前記 Scheuring の說に賛成するもので ある.

\section{0. 總括並に結論}

以上の諸實驗の成績を要約すれてば火火悀りである。

1. 蒸馏水を溶媒とするKolloid-銀溶液を家鬼の靜脈內に注射した處が溥い溶液程致 死作用が强い.

2. 余の實驗條件の下では $2 \%$ Kolloid-銀對 $\mathrm{kg} 8 \mathrm{cc}$ が最小玫死量であつた.

3. 最小致死量即ち $2 \%$ Kolloid-銀對 $\mathrm{kg} 8 \mathrm{cc}$ を注射する代りに，之を 2 分して $20 \%$

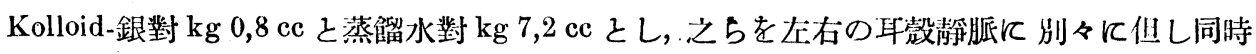
に注射すれば每常急性死を起す事が出來た。

4. 上記の分割注射法に於て蒸餾水 7,2 cc の代りに生理的食搵水 $7,2 \mathrm{cc}$ を注射したの では急性死は起をない。

5. 生理的食盐水を溶媒とする Kolloid-銀溶液では銀の絕對量に於ては最小致死量の 倍量を注射しても急性死を起す事はない。

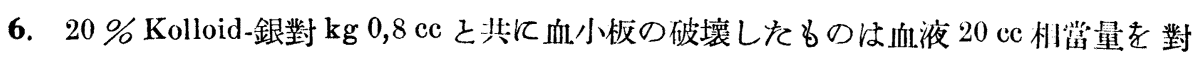
$\mathrm{kg}$ 量として注射しても Schock-症狀を呈するが急性死を起さない.

7. $20 \%$ Kolloid-銀對 $\mathrm{kg} 0,8 \mathrm{cc}$ 己其に赤血球の溶解したるのは血液 $0,5 \mathrm{cc}$ 相當量（全 血液の $0,9 \%$ ）を對 $\mathrm{kg}$ 量として注射したらば急性死を起した。

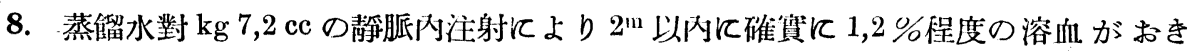
る.

9. 溶解赤血球液は全血量の 1 制相當量でもとだりを單獨に注射したのでは急性死を 起す事はない。

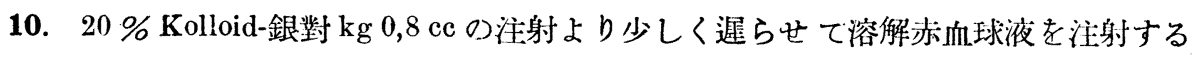

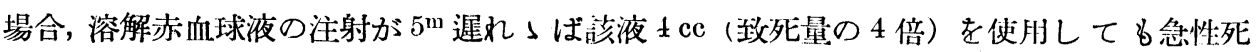
はおきない，

11. 赤血球成分中 Kolloid-銀と共働して急性死を若起する物質は赤血球の冈漿沉も少 


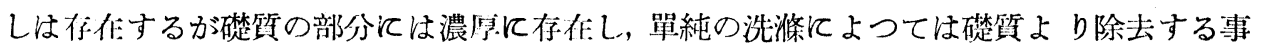
は困難である。

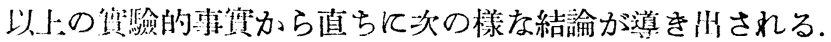

a. 血管河血液凝固現象に基く定型的急性:死の發生には膠質溶液の溶媒が蒸䬰水であ る事が必要である。

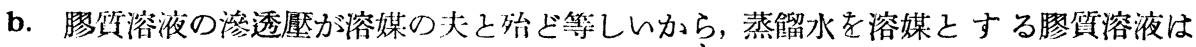
靜脈內に注射された場合飞輕度の溶血現象をおてし赤血球中に含有されて居るThrombokinase 系流小に遊離させ, 之が血管內血液凝固の口火を切るのである.

c. 溶血現象が作はなければ䇥型的急性死は潑生しないけれ ど，溶血現象は滕質の作

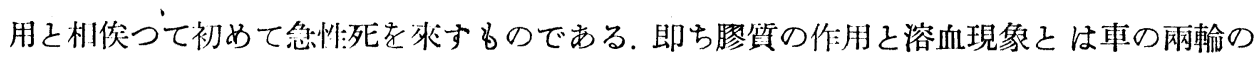
如く急性死の發仯には其に不可缺の要素である。

d. 賿摈溶液が稀䆁される程致死作用が强くなるのは稀薄溶液の使用は大量注射を意 味し, 從つて溶血現像の简监によるThrombokinase 遊離量の增州を來すからである.

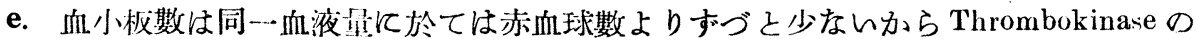
保持者としては從來一般に信ぜられて剧る程付力なものではない.今後は Thrombokinase に關しては赤血球てそ注目せらるべきものだある。

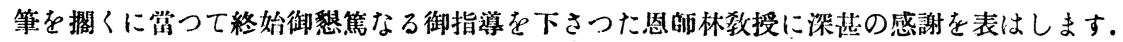

\section{引用 目}

1) Rost: Zbl. Path. 24, 97 (1913).

2) 牛田：東宗鳘學會稚誌 42, 437 (昭和 3 年).

3) Messini: Arch. exper. Pathol. 127, 366 (1927).

4) 加藤：生理學 第 4 版。下卷, 230 (昭和 2 年).

5) '加藤：上揭書第 4 版。 上参, 61 (昭和 2 年).

6) Mrrawitz: Asher u. Spiro, Ergebnisse. d. Physiol. 4, 421 (1905).

7) Fonio: Bethe. Handb. d. Norm. u. Pathol. Physiol. VI/I, 310 (1928).

8) Scheuring: Arch. exper. Pathol. 177: 674 (1934).

9) 白井, 安藤：寞驗動物0)實際 93 (昭和 7 年).

10）日野下. 愛知警學會雜誌 40, 107 (昭和 8 年)。

11) 白井, 安藤: 寞驗動物の實際 81 (昭和 7 年).

12) Bürler : Bethe. Handb. d. Norm. u. Pathol. Physiol. VI/I, 27 (1928).

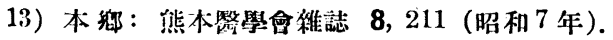

14) 山口：東宗繁學會稚誌 54, 764 (昭和 15 年).

15) 今川：千葉嶇學會雜誌 16, 1081 (昭和 13 年). 
einem gewissen Stadium immer Pupillenverengerung bewirkt wie bei Menschen, stellten sie Versuche an diesen Tieren an, um die Entstehung dieser Pupillenveränderung zu erforschen. Die Äthermiosis erfolgte auch in Versuchen, bei denen Erstickung durch Ausführung künstlicher Atmung vermieden worden war. Sie blieb aber an einem Auge, dessen Sympathicus und Occulomotorius durchschnitten worden waren, gänzlich aus. Sie trat an einem Auge mit dem durchschnittenen Halssympathicus auf, aber an einem solchen mit dem durchschnittenen Occulomotorius gar nicht. Die Äthermiosis trat an beiden Augen nach Abtragung des Grosshirns und Thalamus ebenfalls auf, während sie nach der des Vierhügels vollständig ausblieb. Aus diesen Resultaten zogen Verff. den Schluss, dass die Äthermiosis durch die Wirkung des Äthers auf den parasympathischen Mechanismus im Vierhügel zustande kommt, wenn es auch noch unentschieden bliebt, ob das Occulomotoriuszentrum dabei mittelbar oder unmittelbar erregt wird. [Vgl. Original (japanisch) S. 238.]

(Autoreferat.)

Ueber den Entstehungsmechanismus des akuten Todes bei der intravenösen Injektion kolloidaler Substanzen.

\section{(I. Mitteilung)}

Von

\section{Naotosi Kumagai}

Aus dem Pharmakologischen Institut der Medizinischen Fakultät zu Tiba.

(Direktor: Prof. Dr. Inosuke Mayyasi.)

Eingegangen ain 25. Mürz 1942.

In seinem Studium über den Entstehungsmechanismus des akuten Todes bei der intravenösen Injektion kolloidaler Substanzen versuchte der Verfasser zunächst die von einigen Autoren bestätigte 'Tatsache zu erklären, dass die Giftigkeit einer kolloidalen Lösung von ihrer Konzentration stark beeinflusst werde und daher die minimale letale Dose schwer festzustellen sei. Da man bis heute bei solchen Untersuchungen immer destilliertes Wasser als Lösungsmittel für die Kolloidsubstanz zu gebrauchen pflegte und hinsichtlich des osmotischen Drucks solche Lösungen sich fast wie destilliertes Wasser verhalten, so sollte man bei ihrer Injektion neben den eigentlichen Wirkungen dẹ Substanz auch gewisse Schädigungen der Blutelemente durch so stark hypotonische Lösungen nicht übersehen. Darüber führte nun der Verfasser die Reihen der unten erwähnten Experimente mit Kolloidsilber "Sakuragi” durch. Als Versuchstiere wurden weisse Kaninchen verwendet.

Zuerst wurde festgestellt, dass die Giftigkeit der Kolloidsilberlösung mit 
ihrem Verdünnunggrad zunahm und die minimale letale Dose bei $2 \%$ iger Lösung $8 \mathrm{~cm}$ pro $\mathrm{kg}$ Körpergewicht betrug. Hier teilte der Verfasšer diese letale Dose in zwei Teile, nämlich $0,8 \mathrm{ccm} 20 \%$ ige Lösung und 7,2 ccm destilliertes Wasser. Da die $2 \%$ ige und die $20 \%$ ige Kolloidlösung praktisch denselben osmotischen Druck wie destilliertes Wasser haben, dürfte die lefale Dose auch bei so geteilter Applikation ihre Wirkungen kaum verändern. Wènn man diese zwei Teile getrennt aber gleichzeitig in der Weise applizierte, indem man in die eine Ohrvene $0,8 \mathrm{ccm} 20 \%$ ige Lösung und gleichzeitig in die andere 7,2 ccm destilliertes Wasser injizierte, so wurde der akute Tod auch bei dieser Applikationsweise immer beobachtet, wobei festgestellt werden konnte, dass sein Eintreten ganz und gar von der Mitinjektion des Wassers bedingt war. Daher galt die nächste Untersuchung der Frage, was für eine Bedeutung denn diese Mitinjektion des Wassers haben könnte. Jedes Formelement, welches aus Zitratblut isoliert und einige Male mit physiologischer Kochsalzlösung gewaschen wurde, zerfiel in destilliertem Wasser. Man fügte dann einer so bereiteten Emulsion eine genügende Menge Kochsalz hinzu, um sie blutisotonisch zu machen. Durch die folgenden Untersuchungen wurde festgestellt, dass unter solchen Emulsionen die Erythrozytenemulsion allein dazu befähigt war, intravaskuläre Koagulation hervorzurufen, wenn sie an Stelle von 7,2 ccm destilliertem Wasser bei der oben erwähnten geteilten Darreichung der letalen Dose injiziert wurde. Dagegen hatte die Blutplättchenemulsion diese Fähigkeit nicht.

Der Verfasser konnte weiter konstatieren, dass durch die Hypotonie der eingespritzten Kolloidlösung eine genügende Menge von Erythrozyten zerfällt, um den akuten Tod hervorzufen.

Nun wollte der Verfasser wissen, ob sich der in dieser Weise wirkende Stoff, welcher wohl die sogenannte Thrombokinase sein dürfte, in dem Endoplasma oder an dem Stroma der Erythrozyten befand. Und die Experimente zeigten, dass das stromafreie Endoplasma wohl dieselbe Wirkung hatte, aber für das Eintreten des Todes etwa eine 4-fach so grosse Menge desselben wie die des stromahaltigen notwendig war. Andererseits gelang es dem Verfasser kaum, das Stroma durch wiederholte Waschung mit physiologischer Kochsalzlösung vollkommen wirkungslos $\mathrm{zu}$ machen. Von diesen eigenen Untersuchungen auskam der Verfasser mit Scheuring zu völliger Übereinstimmung der Ansicht, dass nämlich die Thrombokinase an den Erythrozyten, besonders an ihrem Stroma, adsorbiert sei. Um es kurz zusammenzufassen, so wird bei der intravenösen Injektion der gebräuchlichen letalen Dose von Kolloidsilberlösung durch ihre osmotische Hypotonie eine kleine Menge Erythrozyten zum Zerfall gebracht, wodurch ein unbekannter Stoff, der hauptsächlich an dem Erythrozytenstroma adsorbiert ist, in die Blutbahn freigelassen wird. Dieser Stoff, der wahrscheinlich die 'Thrombokinase ist, kann im Zusammenwirken mit dem Kolloidsilber die intravaskuläre Koagulation hervorrufen. Je verdünnter die injizierte Kolloidsilberlösung ist oder, was desselbe ist, je reichlicher destilliertes Wasser 
intravenös mitinjiziert wird, desto mehr Erythrozyten zerfallen und umsomehr Thrombokinase wird frei.

So erklärt nun der Verfasser den Einfluss der Konzentration kolloidaler Lösungen auf ihre Giftigkeit. Zu gleicher Zeit, wie oben erwähnt, ist es dem Veffasser gelungen, eine bis heute unbekannte Stufe der Entwicklung des akıten Todes zu klären. Auch hat er bewiesen, dass die Thrombokinase des Kaninchenblutes grösstenteils in den Erythrozyten enthalten ist und daher die Thrombozyten als Lieferanten der Thrombokinase hinter den Erythrozyten weit zurückstehen. [Vgl. Original (japanisch) S. 243.]

(Autoreferat) 